


\section{Split-feeding en twice a day-feeding voeren bij vleeskuikenouderdieren}

Rick van Emous, Annemarie Mens en Gisabeth Binnendijk

Dit onderzoek is uitgevoerd door Wageningen Livestock Research binnen het kader van de Publiek Private Samenwerking (PPS) "Breeders In Technology" BITe (BO-63-001-033). Dit project is een samenwerking tussen het Ministerie van Landbouw, Natuur en Voedselkwaliteit en een consortium van verschillende partijen. 
R.A. van Emous, A.J.W. Mens en G.P. Binnendijk, 2020. Split-feeding en twice a day-feeding bij vleeskuikenouderdieren. Wageningen Livestock Research, Rapport 1272.

In dit rapport worden de resultaten gepresenteerd van een studie naar het toepassen van split-feeding (= apart ochtend- en middagvoer) en twice a day-feeding (standaard voer) t.o.v. eenmaal daags voeren (standaard voer) bij vleeskuikenouderdieren tijdens de late legperiode (van 50 - 60 weken leeftijd). Dit experiment is uitgevoerd in opdracht van het Consortium Breeders In Technology (BITe) en het Ministerie van Landbouw, Natuur en Voedselkwaliteit. Uit het onderzoek blijkt dat dieren die split-feeding kregen een hogere productie hadden tussen 51 en 55 weken leeftijd. Verder gaf het toepassen van tweemaal daags voeren (twice a day-feeding en split-feeding) nauwelijks effecten op productie en broedeikwaliteit. Wel werd bij de verschillende voerstrategieën een duidelijk ander gedragspatroon gedurende de dag waargenomen. De tweemaal daags gevoerde dieren (twice a dayfeeding en split-feeding) vertoonden t.o.v. eenmaal daags gevoerde dieren meer eet en rust gedrag en minder foerageer en pik gedrag. Verder onderzoek met een aangepaste opzet van het experiment is wenselijk om uit te zoeken wat de voordelen op reproductie, broedeikwaliteit en gedrag zijn van split-feeding en twice a day-feeding.

Dit rapport is gratis te downloaden op https://doi.org/10.18174/531161 of op www.wur.nl/livestock-research (onder Wageningen Livestock Research publicaties).

Dit werk valt onder een Creative Commons Naamsvermelding-Niet Commercieel 4.0 Internationaallicentie.

(c) Wageningen Livestock Research, onderdeel van Stichting Wageningen Research, 2020

De gebruiker mag het werk kopiëren, verspreiden en doorgeven en afgeleide werken maken. Materiaal van derden waarvan in het werk gebruik is gemaakt en waarop intellectuele eigendomsrechten berusten, mogen niet zonder voorafgaande toestemming van derden gebruikt worden. De gebruiker dient bij het werk de door de maker of de licentiegever aangegeven naam te vermelden, maar niet zodanig dat de indruk gewekt wordt dat zij daarmee instemmen met het werk van de gebruiker of het gebruik van het werk. De gebruiker mag het werk niet voor commerciële doeleinden gebruiken.

Wageningen Livestock Research aanvaardt geen aansprakelijkheid voor eventuele schade voortvloeiend uit het gebruik van de resultaten van dit onderzoek of de toepassing van de adviezen.

Wageningen Livestock Research is NEN-EN-ISO 9001:2015 gecertificeerd.

Op al onze onderzoeksopdrachten zijn de Algemene Voorwaarden van de Animal Sciences Group van toepassing. Deze zijn gedeponeerd bij de Arrondissementsrechtbank Zwolle. 



\section{Inhoud}

$\begin{array}{ll}\text { Woord vooraf } & 6\end{array}$

$\begin{array}{lc}\text { Samenvatting } & 8\end{array}$

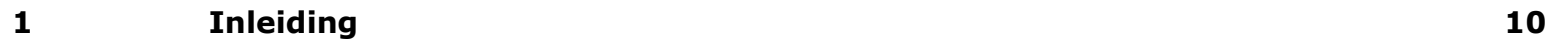

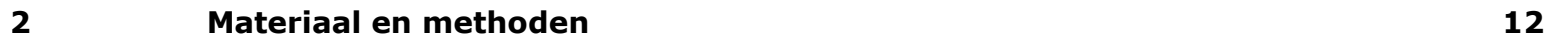

2.1 Dieren 12

2.2 Huisvesting en verzorging $\quad 12$

$\begin{array}{lll}2.3 & \text { Experimentele opzet } & 13\end{array}$

2.4 Waarnemingen 14

2.4.1 Analyses in grondstoffen en voeders 14

2.4.2 Lichaamsgewicht hennen en hanen 14

2.4.3 Productie resultaten 14

2.4.4 Broederijresultaten 14

2.4.5 Broedeikwaliteit 14

2.4.6 Gedrag 16

2.4.7 Bevedering 16

2.5 Statistische analyse 16

$\begin{array}{llr}3 & \text { Resultaten } & 17\end{array}$

$\begin{array}{lll}3.1 & \text { Verloop experiment } & 17\end{array}$

$\begin{array}{lll}3.2 & \text { Analyse voeders } & 17\end{array}$

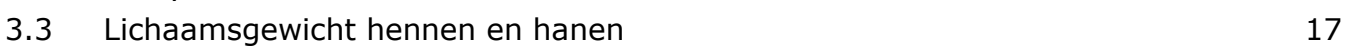

3.4 Productieresultaten $\quad 18$

$\begin{array}{ll}3.5 & \text { Broederijresultaten } \\ 3.6 & 19\end{array}$

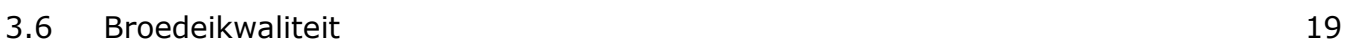

$\begin{array}{lll}3.7 & \text { Gedrag } & 20\end{array}$

$\begin{array}{lll}3.8 & \text { Bevedering } & 24\end{array}$

4

$\begin{array}{ll}\text { Discussie } & 25\end{array}$

4.1 Effect voerstrategie op productieresultaten $\quad 25$

$\begin{array}{lll}4.2 & \text { Effect voerstrategie op broederijresultaten } & 25\end{array}$

$\begin{array}{lll}4.3 & \text { Effect voerstrategie op broedeikwaliteit } & 25\end{array}$

$\begin{array}{lll}4.4 & \text { Effect voerstrategie op gedrag } & 26\end{array}$

$5 \quad$ Conclusies en aanbevelingen $\quad 29$

$\begin{array}{ll}\text { Literatuur } & \mathbf{3 0}\end{array}$

Bijlage 1 Schematisch overzicht hok 32

Bijlage 2 Samenstelling voeders $\quad 33$

$\begin{array}{lll}\text { Bijlage } 3 & \text { Ethogram algemeen gedrag } & 34\end{array}$ 


\section{Woord vooraf}

Door aanpassingen aan de fokdoelen veranderen vleeskuikenouderdieren continue. Hierdoor zijn ook aanpassingen nodig aan de houderij en management van deze dieren. Het huidige moderne ouderdier is persistenter op productie en bevruchting dan ouderdieren 10 tot 20 jaar terug. Daardoor is het idee ontstaan om de dieren langer aan te houden dan de gebruikelijke circa 60 weken leeftijd. Een langere productieperiode/levensduur is een stap voorwaarts naar een meer duurzamere houderij van vleeskuikenouderdieren. Er worden minder dieren opgezet, ze leven langer, verminderde arbeid, verhoogde productie per dier, etc. Deze zaken passen allemaal in een transitie naar een nieuwe manier van het houden van vleeskuikenouderdieren die toekomstbestendig is.

In dit rapport worden de resultaten gepresenteerd van een experiment met vleeskuikenouderdieren tijdens de late legperiode, waarbij de dieren verschillende voerstrategieën kregen. Deze studie is uitgevoerd door Wageningen Livestock Research in opdracht van, en gefinancierd door het Consortium Breeders In Technology en het Ministerie van Landbouw, Natuur en Voedselkwaliteit. Het hier beschreven onderzoek kan bijdragen aan aangepast management om vleeskuikenouderdieren langer aan te houden.

De auteurs bedanken de partners (Ministerie van LNV, PLUIMNED (Stuurgroep opfok en vermeerdering LTO/NOP en NVP), ABZ Diervoeding, Aviagen-EPI, De Heus Voeders, De Hoop Mengvoeders, EW Nutrition, For Farmers, Hubbard, Trouw Nutrition, Sommen en Veterinair Centrum Someren) binnen het project Breeders In Technology voor de prettige samenwerking. Daarnaast bedanken we de studenten (Huib van den Heuvel, Adri Mertens en Jan Peter le Poole) van HAS Den Bosch voor hun hulp bij de verwerking en analyse van de resultaten.

Projectleider

Dr. ing. R.A. (Rick) van Emous 


\section{Samenvatting}

\section{Aanleiding en doel}

De toenemende persistentie op productie en bevruchting bij vleeskuikenouderdieren was de aanleiding om onderzoek te initiëren om de dieren langer dan gebruikelijk (60-62 weken leeftijd) aan te houden. Het verlengen van de legperiode is interessant doordat de aankoopkosten van de opfokhen verdeeld kan worden over een langere productieperiode, er meer eieren per dier geproduceerd worden en er minder arbeid nodig is voor vaccinatie, laden en reinigen. Voor het verlengen van de legperiode bij ouderdieren is gekeken naar de kennis die de laatste jaren is opgedaan in de leghennen sector. Daar heeft men al jaren ervaring met het verlengen van de legperiode en worden de leghennen in het laatste decennium gemiddeld een week per jaar langer gehouden. Bij leghennen wordt de transitie naar een langere productieperiode ondersteund door verschillende experimenten en daaruit volgende aanpassingen aan management. Een van de onderzoeksrichtingen is het toepassen van split-feeding waarbij de dieren een op de specifieke behoefte aangepast ochtend- en middagvoer verstrekt krijgen. $\mathrm{Bij}$ vleeskuikenouderdieren is tot nu toe echter nauwelijks onderzoek uitgevoerd naar het verlengen van de productieperiode en dus ook niet naar split-feeding.

Het doel van het onderzoek was daarom om de effecten te bestuderen van split-feeding en twice a day-feeding t.o.v. eenmaal per dag standaard voer verstrekken op de (re)productie, eischaalkwaliteit en gedrag bij vleeskuikenouderdieren.

\section{Dieren, huisvesting en verzorging}

De proef werd uitgevoerd tussen 50 en 60 weken leeftijd met 24 hennen en 2 hanen per hok (Ross 308). De dieren werden gehouden in twee afdelingen met elk 12 hokken (24 in totaal). De hokken waren elk 2,5 bij 2,0 meter breed ( $5 \mathrm{~m}^{2}$ ). Er was een houten rooster (150 bij $100 \mathrm{~cm}$ ) geïnstalleerd met aangrenzend buiten het hok een legnest $(90 \times 40 \mathrm{~cm})$. Verder waren per hok 2 kunststof zitstokken (rechthoekig met afgeronde hoeken) met een totale lengte van 4 meter geïnstalleerd. De voervoorziening voor de hennen bevond zich op het strooisel in 2 voergoten met grill (totaal 3,7 m lengte) per hok. De hanen werden ook op het strooisel gevoerd via een aparte voergoot op $50 \mathrm{~cm}$ hoogte. Water werd tussen 07:30 en 16:30 verstrekt via een drinknippellijn (7 nippels/hok) welke zich boven het rooster bevond. In de namiddag (15:00 uur) kregen de dieren $2 \mathrm{gram} /$ dier strooigraan in het strooisel verstrekt. Verder kregen de dieren eenmaal per week (500 gram/hok) grit verstrekt om de schaalkwaliteit te ondersteunen. De lichtperiode stond ingesteld op 14 uur licht (02:30 t/m 16:30 uur) en de lichtsterkte was minimaal 40 lux op kophoogte. Gedurende het experiment stond de streeftemperatuur ingesteld op $20^{\circ} \mathrm{C}$. Gedurende de dag was er een radio met geluid om de dieren rustiger te houden.

\section{Experimentele opzet}

In dit experiment werden drie verschillende behandelingen (voer strategieën) toegepast met elk 8 herhalingen (hokken). De eerste groep dieren kreeg eenmaal daags (07:30 uur) controlevoer (CON1x groep) (standaard foktoomvoer 3). De tweede groep dieren kreeg tweemaal daags (50\% om 07:30 en $50 \%$ om 14:00 uur) controlevoer (standaard foktoomvoer 3 ) verstrekt (twice a day-feeding $=$ CON2x groep). De derde groep dieren kreeg tweemaal daags (07:30 en 14:00 uur) twee verschillende voersoorten verstrekt (split-feeding $=\mathbf{S P 2} \mathbf{x}$ groep). Het ochtendvoer bij split-feeding was energetisch gelijk aan het controlevoer, maar het bevatte meer eiwit en fosfor $(P)$ en minder calcium (Ca). Het middagvoer had een lager energie-, eiwit- en P-gehalte en een hoger Ca-gehalte t.o.v. het controlevoer en het ochtendvoer. De dieren kregen een vooraf bepaalde voerhoeveelheid verstrekt zodat alle dieren van de verschillende behandelingen hetzelfde gewichtsschema volgden.

\section{Waarnemingen}

De volgende waarnemingen werden verricht:

- De belangrijkste ingrediënten en de geproduceerde voeders werden geanalyseerd op droge stof, ruw eiwit, ruw vet, ruwe celstof, ruw as, zetmeel, suikers, Ca en P.

- Tweewekelijks werd het lichaamsgewicht van de hennen en hanen vastgesteld.

- Dagelijks werden de volgende productieresultaten verzameld: voer- en wateropname, uitval, eiproductie en -gewicht en uitsortering tweede soort eieren. 
- Eenmaal per week werd het eigewicht bepaald van de $1^{\mathrm{e}}$ soort eieren.

- Op 55 en 60 weken leeftijd werden 50 broedeieren per hok verzameld en zeven dagen bebroed om de bevruchting en embryonale sterfte na zeven dagen te bepalen.

- Bij tien $1^{\mathrm{e}}$ soort broedeieren per hok werd op 56 en 59 weken leeftijd de eischaaldikte gemeten.

- De maximale breuksterkte en de stijfheid (een maat voor de flexibiliteit) van de eischaal werd op 53, 56 en 59 weken leeftijd bepaald bij tien $1^{\text {e }}$ soort eieren per hok.

- Bij 30 broedeieren per hok werd op 56 en 59 weken leeftijd de egg mottling bepaald. Egg mottling is een maat voor de aanwezigheid van doorschijnende vlekken in de eischaal.

- Van 10 ( $1^{\mathrm{e}}$ soort) broedeieren per hok werd op 51, 53 en 56 weken leeftijd de albumen/dooier verhouding en het schaalgewicht bepaald.

- Het gedrag van de hennen werd op 54 en 59 weken leeftijd geobserveerd met behulp van scan sampling. Waarnemingen vonden plaats gedurende de lichtperiode, in acht ronden per waarnemingsdag. Daarbij werd ook de plaats (strooisel, rooster en zitstok) genoteerd waar de dieren verbleven.

- De kwaliteit van het verenpakket werd op 55 en 60 weken leeftijd van 6 dieren/hok beoordeeld.

\section{Resultaten}

Een tendens tot een hoger leg\% $(P=0,088)$ tussen 51 en 55 weken leeftijd werd aangetoond voor de SP2x t.o.v. de CON1x dieren. Voor de andere productieresultaten werden geen significante verschillen gevonden.

Er werden geen effecten van de verschillende voerstrategieën gevonden op broederijresultaten en broedeikwaliteit (\%breuk/kneus/wind eieren, schaaldikte, breuksterkte, egg mottling, schaalgewicht en albumen/dooier verhouding).

De tweemaal per dag gevoerde dieren (CON2x en SP2x) vertoonden duidelijk een ander gedragspatroon dan de eenmaal per dag gevoerde dieren. De dieren die eenmaal per dag gevoerd werden besteedden gedurende de dag minder tijd aan eet- en drinkgedrag. De dieren die tweemaal per dag gevoerd werden besteedden 's morgens relatief minder tijd aan voer- en wateropname, omdat zij 's ochtends 50\% van de dagportie verstrekt kregen en dit sneller opnamen dan de eenmaal per dag gevoerde dieren. In de middag was na de tweede voerbeurt een duidelijke stijging van het voer- en wateropnamegedrag te zien. Uit de observaties bleek verder dat de dieren die tweemaal per dag gevoerd werden in de ochtend en rond de middag voor de tweede voerbeurt meer tijd besteden aan rusten (staan en zitten). Die dieren die eenmaal per dag gevoerd werden, vertoonden meer inactief gedrag aan het einde van de dag. De dieren die tweemaal per dag gevoerd werden vertoonden, aan het einde van de dag, minder pikgedrag (naar objecten en kippen) dan de eenmaal per dag gevoerde dieren.

\section{Conclusie}

Uit het onderzoek blijkt dat dieren die split-feeding kregen een hogere productie hadden tussen 51 en 55 weken leeftijd. Verder gaf het toepassen van tweemaal daags voeren (twice a day-feeding en splitfeeding) nauwelijks effecten op productie en broedeikwaliteit. Wel werd bij de verschillende voerstrategieën een duidelijk ander gedragspatroon gedurende de dag waargenomen. De tweemaal daags gevoerde dieren vertoonden t.o.v. eenmaal daags gevoerde dieren meer eet en rust gedrag en minder foerageer en pik gedrag. Verder onderzoek met een aangepaste opzet van het experiment is wenselijk om uit te zoeken wat de voordelen op reproductie, broedeikwaliteit en gedrag zijn van splitfeeding en twice a day-feeding. 


\section{$1 \quad$ Inleiding}

Het doel van het houden van vleeskuikenouderdieren is het produceren van $1^{\mathrm{e}}$ soort bevruchte broedeieren met een goede, sterke schaal. Door de continue genetische veranderingen dient echter ook het management aan de dieren te worden aangepast. In Noordwest Europa starten (door lichtstimulatie rond 21 weken leeftijd) vleeskuikenouderdieren met eieren produceren op 22 tot 23 weken leeftijd en worden de dieren meestal tot 60 en maximaal 62 weken leeftijd aangehouden. Op andere continenten (bijv. Noord- en Zuid-Amerika) worden vleeskuikenouderdieren vaak tot ongeveer 65 weken leeftijd aangehouden. In deze landen worden de dieren op latere leeftijd met licht gestimuleerd (vanaf 23 i.p.v. 21 weken leeftijd), waardoor ze ook enige weken later in productie komen. Dit doet men omdat de ondergrens voor het broedeigewicht in die regionen vaak $52 \mathrm{gram}$ is, terwijl die in Europa 50 gram is. Wanneer dieren later gestimuleerd worden om in productie te komen, hebben ze gedurende de opfok meer vetreserves opgebouwd. Met deze reserves kunnen ze mogelijk perioden met een negatieve energiebalans (rond de piekproductie) beter doorstaan. Dit resulteert in een verhoogde persistentie in productie en bevruchting/uitkomsten waardoor het economisch rendabel is om de dieren langer aan te houden. Naast de verbeterde reproductie is het bij langer aanhouden van ouderdieren belangrijk dat ook de schaalkwaliteit van de broedeieren goed blijft. Een verminderde schaalkwaliteit heeft invloed op het aantal $1^{\mathrm{e}}$ soort broedeieren, uitkomstpercentage en kuikenkwaliteit.

De kwaliteit van de eischaal neemt aan het eind van de productieperiode bij de meeste koppels vleeskuikenouderdieren af. In de praktijk wordt vanaf 40 weken leeftijd een voer verstrekt met een verhoogd calciumniveau en wordt extra grit verstrekt om de schaalkwaliteit te ondersteunen. Een aantal bedrijven in de legsector $(<5 \%)$ past in de tweede helft van de legperiode split-feeding (speciaal ochtend- en middagvoer) toe om de eivorming/eischaalvorming te faciliteren. De Los Mozos en Sanchez (2014) hebben onderzoek gedaan naar het toepassen van split-feeding bij leghennen op oudere leeftijd (tussen 95 en 98 weken). De split-feeding dieren ontvingen gedurende de ochtend een voer dat meer tegemoet komt aan de behoefte van eivorming (energie en eiwit) en tijdens de namiddag een voer om de eischaalvorming (calcium) te faciliteren. Ondanks de lagere opname aan nutriënten was het eischaalgewicht $(+1.3 \%)$, eischaaldikte $(+1.3 \%)$ en eischaalgewicht per oppervlakte $\left(+1.9 \% ; \mathrm{mg} / \mathrm{cm}^{2}\right)$ hoger. Daarnaast zag men tussen 95 en 98 weken leeftijd $30 \%$ minder breuk en windeieren. Uit onderzoek van van Krimpen et al. (2018) bleek verder dat het toepassen van split-feeding bij biologische leghennen een lagere fosforuitscheiding gaf zonder negatieve effecten op eiproductie en schaalkwaliteit. Trouw Nutrition heeft een experiment met split-feeding met vleeskuikenouderdieren uitgevoerd (Jansen, persoonlijke mededeling). De eiproductie en het aantal kuikens per ouderdier bleek bij split-feeding hoger dan bij de controlegroep die eenmaal per dag werden gevoerd. Tevens waren de voerkosten per ouderdier lager omdat de toegepaste voeders gemiddeld goedkoper waren. Ander onderzoek met split-feeding met ouderdieren is niet beschikbaar. Er is wel onderzoek gedaan naar meerdere keren per dag of op verschillende tijdstippen per dag voer verstrekken aan ouderdieren.

In verschillende studies (de Avila et al., 2003; Spradley et al., 2008; Taherkhani et al., 2010; Moradi et al., 2013; Soltanmoradi et al., 2013) vond men dat vleeskuikenouderdieren bij twice a day-feeding een hogere eiproductie hadden in vergelijking met dieren die eenmaal (in de ochtend) werden gevoerd. Geen effecten van verschillende voertijdstippen op productie werden in de studies van Cave (1981), Bootwalla et al. (1983) en Samara et al. (1996) aangetroffen. Ook Backhouse en Gous (2005) onderzochten verschillende voertijdstippen bij vleeskuikenouderdieren: 07:30, 9:30, 11:30, 13:30 en 15:30 uur. Daarnaast pasten zij een behandeling toe waarbij dieren de helft van de dagelijkse voergift kregen om 7:30 en om 15:30 uur. Zij vonden geen effecten op de totale eiproductie tussen 26 en 32 weken leeftijd. In een recent onderzoek van Londero et al. (2015) werden Cobb vleeskuikenouderdieren tussen 28 en 40 weken leeftijd op drie verschillende tijdstippen gevoerd: 08:00 (100\%), twice a day-feeding (50\% om 08:00, 50\% om 15:00 uur) of 15:00 uur (100\%). De dieren die om 08:00 uur (100\% voer) of tweemaal per dag werden gevoerd hadden een hogere productie dan de dieren die om 15:00 uur (100\% voer) werden gevoerd. 
Bijna 40 jaar terug vond Cave (1981) dat het eigewicht hoger was voor hennen die twee- of driemaal t.o.v. eenmaal per dag werden gevoerd. In het experiment van Londero et al. (2015) hadden vleeskuikenouderdieren die om 15:00 uur werden gevoerd een hoger eigewicht dan de dieren die om 8:00 uur werden gevoerd. Moradi et al. (2013) vonden dat dieren bij twice a day-feeding, zwaardere eieren legden in vergelijking met dieren die eenmaal per dag werden gevoerd. Ook Spradley et al. (2008) concludeerden dat het gemiddelde eigewicht, voor de hele productieperiode (20-60 weken leeftijd), hoger was bij dieren die tweemaal per dag werden gevoerd dan eenmaal per dag. Geen effect van tijdstip van voeren op eigewicht werd echter gevonden door Samara et al. (1996) en Harms (1991).

Men veronderstelt dat door het verstrekken van de gehele portie voer in de ochtend, de nutriënten mogelijk niet op het juiste tijdstip van de dag beschikbaar komen om in de behoefte van de ouderdieren te voorzien (Cave, 1981). Dit is vooral belangrijk voor calcium, omdat het een essentieel bestandsdeel is voor de eischaalvorming. De vorming van de eischaal begint in de namiddag en/of vroege avond. Omdat vleeskuikenouderdieren meestal in de ochtend gevoerd worden, begint de schaalvorming dus uren na het verstrekken van de dagportie voer. Vleeskuikenouderdieren nemen, bij een eenmalige voerbeurt in de ochtend, het voer op in twee tot vier uur. Uit onderzoek met vleeskuikenouderdieren bleek dat binnen vier uur na het opnemen van het voer (om 7:00 uur voer verstrekken), meer dan de helft van het opgenomen calcium uit de krop verdwenen was (Farmer et al., 1983b). Uit het onderzoek van Farmer et al. (1983b) bleek verder dat vleeskuikenouderdieren in de eerste vier uur ca. $25 \%$ van het opgenomen calcium in de darmen absorberen. Deze dieren werden om 07:00 uur 's morgens gevoerd en absorbeerden na 11:00 uur vrijwel geen (slechts enkele procenten) calcium meer tot 23:00 uur 's avonds (Farmer et al., 1983b). Het benodigde calcium voor de eischaal wordt dan vanuit de calciumopslag in het bot losgemaakt wat kan resulteren in verminderde botkwaliteit en poot- en karkasproblemen. Door vleeskuikenouderdieren later op de dag te voeren, komt het calcium meer beschikbaar op het moment van schaalvorming (Farmer et al., 1983a). Dit resulteert in een beter calciumgebruik/-benutting (Farmer et al., 1983b; Roland en Farmer, 1984) dat meestal tot uiting komt in een toename van het soortelijk gewicht van de eieren, het gewicht van de schaal en de dikte van de schaal (Backhouse and Gous, 2006). Studies van Farmer et al. (1983a), Bootwalla et al. (1983), Backhouse en Gous (2005) en Londero et al. (2015) toonden aan dat dieren die alleen 's middags voer verstrekt kregen de beste schaalkwaliteit hadden. Experimenten uitgevoerd door Brake (1985), Wilson en Keeling (1991), Samara et al. (1996) en Spradley et al. (2008) toonden echter geen effect aan van tijdstip van voeren op de kwaliteit van de eierschaal.

Uit onderzoek van de Avila et al. (2005) bleek dat dieren die later op de dag gevoerd werden ook later op de dag eieren produceerden. Gauthier (2002) vond dat de gemiddelde verblijftijd van het voer in het darmkanaal van kippen vier uur is. Dit zou kunnen betekenen dat het moment waarop de meeste mest (ochtend) geproduceerd wordt, ook samenvalt met het leggen van de meeste eieren resulterend in meer vieze en vuilschalige eieren. Dit bleek echter niet het geval in onderzoek van Londero et al. (2015).

$\mathrm{Er}$ is beperkt informatie beschikbaar over het effect van verschillende voertijdstippen op broederijresultaten. Uit onderzoek van Spradley et al. (2008) bleek dat het een- of tweemaal per dag voeren geen effect had op broederijresultaten. Daarentegen vonden Soltanmoradi et al. (2013) dat twice a day-feeding een hogere bevruchting en uitkomsten gaf. Londero et al. (2015) vonden geen effecten van voeren om 08:00 uur (100\%), 09:00 en 15:00 uur (50/50\%) en 15:00 uur (100\%) op bevruchting en uitkomst. Wel bleek dat de dieren die om 08:00 uur de volledige voerportie verstrekt kregen een lagere embryonale sterfte ( $9,3 \%$ vs. $12,1 \%$ en $11,8 \%$ ) vertoonden en dus een hogere uitkomst hadden dan de dieren die tweemaal gevoerd werden of alleen in de middag.

Het doel van dit onderzoek is om de effecten te bestuderen van split-feeding (speciaal ochtend- en middagvoer) en twice a day-feeding (standaard voer) t.o.v. eenmaal per dag standaard voer verstrekken op de (re)productie, eischaalkwaliteit en gedrag bij vleeskuikenouderdieren in de periode van 50 tot 60 weken leeftijd. 


\section{Materiaal en methoden}

\subsection{Dieren}

Het experiment werd uitgevoerd tussen 50 en 60 weken leeftijd met Ross 308 vleeskuikenouderdieren afkomstig uit een voorgaand experiment binnen de PPS Breeders In Technology. Bij aanvang van het experiment ( 50 weken leeftijd) vond een selectie plaats van de aanwezige hennen, zodat er gestart werd met 24 hennen per hok. Daarbij werden te lichte, te zware, niet leggende en verwonde dieren verwijderd. Per hok waren 2 hanen aanwezig, wat in totaal resulteerde in 26 dieren per hok. In totaal werd het onderzoek dus uitgevoerd met 576 hennen en 48 hanen.

\subsection{Huisvesting en verzorging}

De vleeskuikenouderdieren werden gehuisvest in afdeling 1 en 2 bij proefaccommodatie Carus, Bornse Weilanden 5 te Wageningen (Figuur 2.1). Beide afdelingen werden mechanisch geventileerd en bevatten elk 2 rijen met 6 hokken ( 24 in totaal). Zie bijlage 1 voor een schematisch overzicht van de hokken.

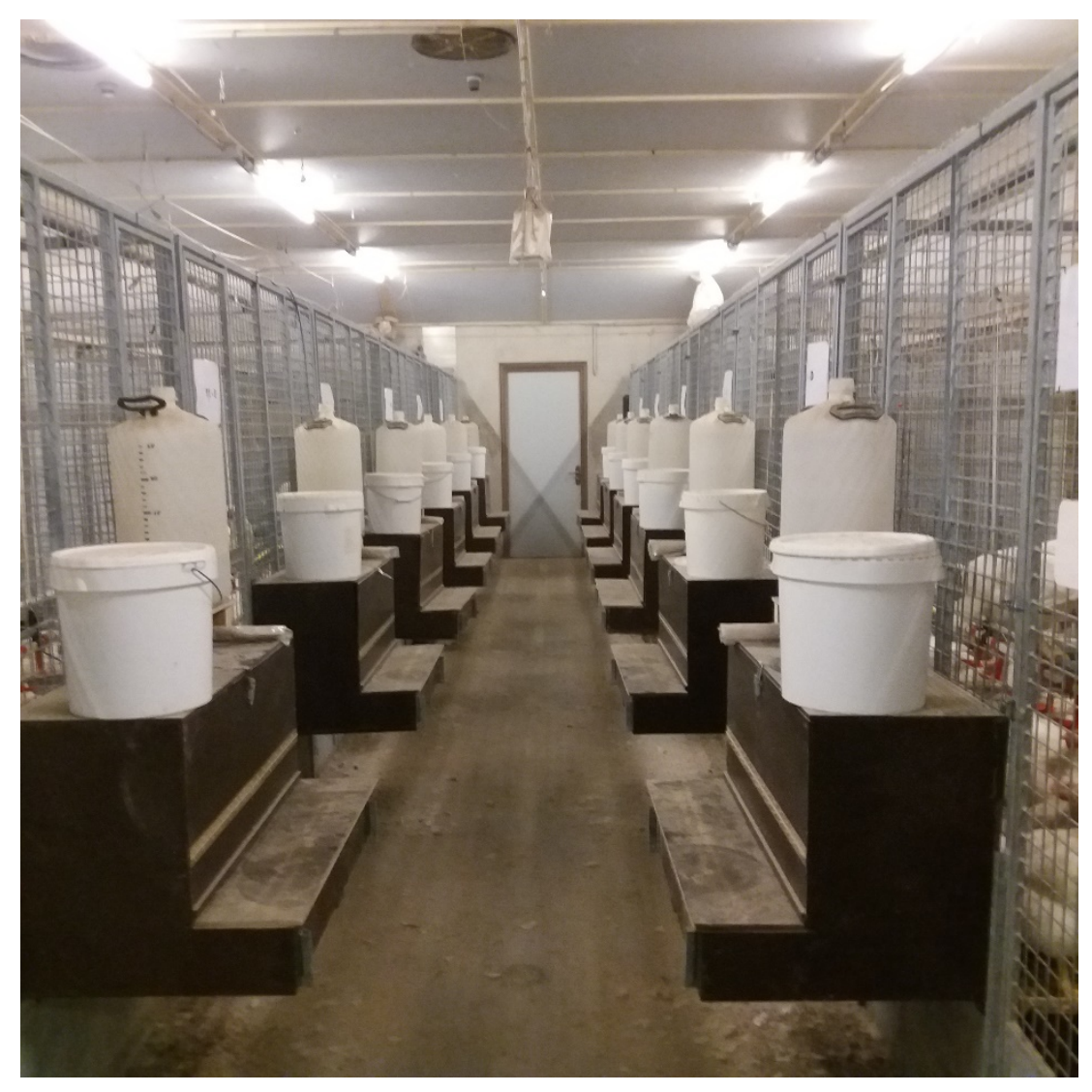

Figuur 2.1 Overzicht van één van de afdelingen met links en rechts de experimentele hokken.

Tussen de hokken zat een dichte afscheiding van $40 \mathrm{~cm}$ waardoor de dieren elkaar niet konden zien om verstoring van het gedrag zoveel mogelijk te voorkomen. De hokken waren elk 2,5 meter diep bij 2,0 meter breed $\left(5 \mathrm{~m}^{2}\right)$. Er was een houten rooster (150 bij $100 \mathrm{~cm}$ ) geïnstalleerd met daaraan grenzend (aan de voorkant buiten het hok) een gemeenschappelijk legnest $(90 \times 40 \mathrm{~cm})$. Verder waren per hok 2 kunststof zitstokken (rechthoekig met afgeronde hoeken, $4 \mathrm{~cm}$ breed en $3 \mathrm{~cm}$ hoog) met een totale lengte van 4 meter geïnstalleerd (Figuur 2.2). 


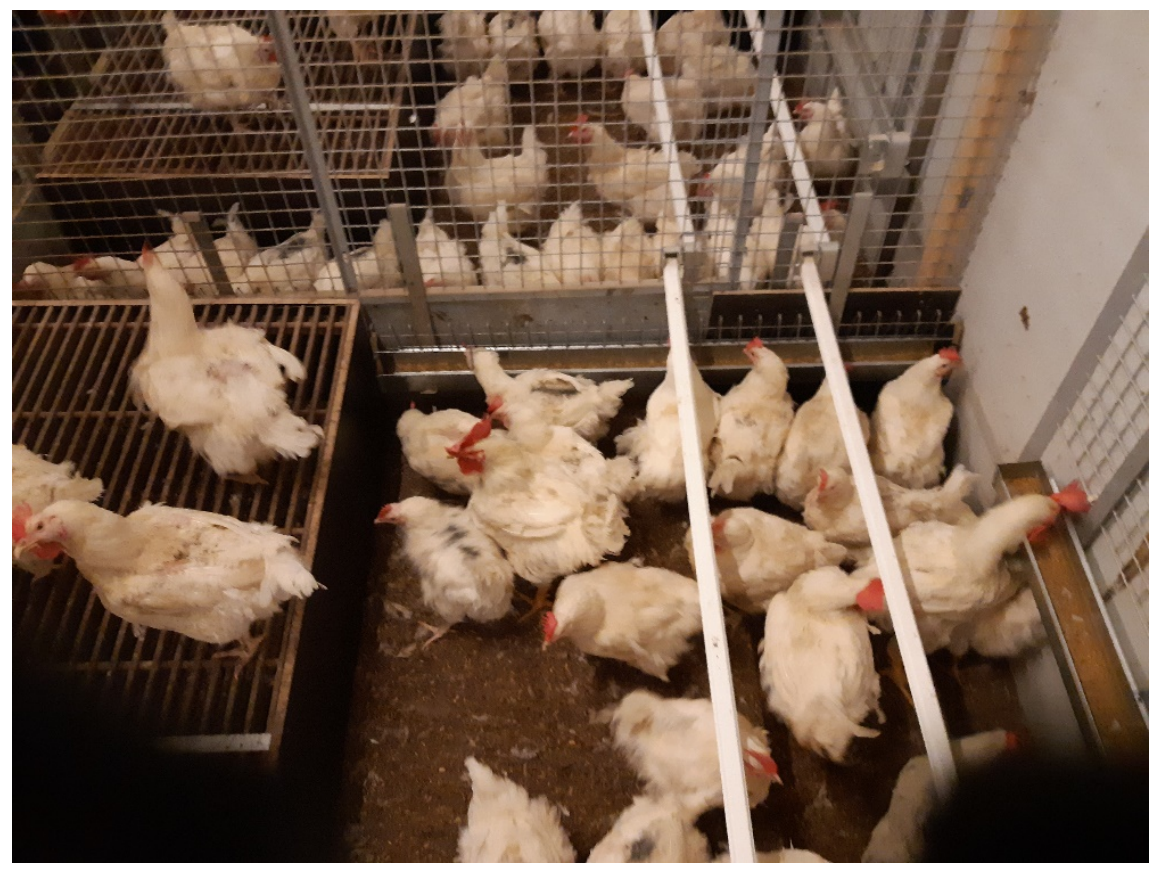

Figuur 2.2 Overzicht van één van de experimentele hokken met links het rooster met daarboven de drinknippellijn (niet zichtbaar) met daarnaast het legnest (niet zichtbaar). Boven en onder (niet zichtbaar) de voergoten voor de hennen, rechts de voergoot voor de hanen en de 2 zitstokken.

Voor aanvang van het experiment werd het oude strooisel verwijderd en een laagje verse houtkrullen over de vloer verspreid $\left(1 \mathrm{~kg} / \mathrm{m}^{2}\right)$. De bezetting was 5,2 dieren (hennen en hanen) per $\mathrm{m}^{2}$ waardoor er per dier $1.923 \mathrm{~cm}^{2}$ ruimte beschikbaar was. De voervoorziening voor de hennen bevond zich op het strooisel in 2 voergoten (totaal 3,7 m lengte) per hok, met een grill om te voorkomen dat hanen toegang hadden tot het voer. Hanen werden op het strooisel gevoerd via een aparte voergoot op 50 $\mathrm{cm}$ hoogte die niet bereikbaar was voor de hennen. De hanen kregen een speciaal hanenvoer met, t.o.v. het foktoomvoer 3, lagere energie, eiwit en Ca gehalten (2.600 kcal/kg AMEn; 13,0\% RE; $0,45 \%$ vert. Lys; $0,5 \%$ vert. $M+C ; 1,0 \%$ Ca; 0,3\% oP). Water werd tussen 07:30 en 16:30 uur verstrekt via een drinknippellijn (7 nippels/hok op het rooster). In de namiddag (15:00 uur) kregen de dieren $2 \mathrm{gram} /$ dier strooigraan op het strooisel verstrekt. Verder kregen de dieren eenmaal per week (500 gram/hok) grit verstrekt in de voergoot om de schaalkwaliteit te ondersteunen. De lichtperiode stond ingesteld op 14 uur licht (van 02:30 t/m 16:30 uur) en de lichtsterkte was minimaal 40 lux op kophoogte. Schaduwplekken werden zoveel mogelijk geminimaliseerd om grondeieren te voorkomen. Gedurende het experiment stond de streeftemperatuur ingesteld op $20^{\circ} \mathrm{C}$. Overdag was er een radio met geluid om de dieren rustiger te houden. Tijdens de proef werden de dieren dagelijks tweemaal door de dierverzorger gecontroleerd op afwijkingen en eventuele uitval werd genoteerd. Dieren met een geconstateerde afwijking werden na overleg met de onderzoekers uit de proef verwijderd.

\subsection{Experimentele opzet}

In dit experiment werden drie verschillende behandelingen (voerstrategieën) toegepast, elk met 8 herhalingen (Tabel 1). De eerste groep dieren kreeg eenmaal daags (07:30 uur) controlevoer (CON1x groep) (= standaard foktoomvoer 3). De tweede groep dieren kreeg tweemaal daags (50\% om 07:30 uur en 50\% om 14:00 uur) controlevoer ( = standaard foktoomvoer 3 ) verstrekt (twice a day feeding $=$ CON2x groep). De derde groep dieren kreeg tweemaal daags (07:30 en 14:00 uur) twee verschillende voersoorten verstrekt (split-feeding = SP2x groep). Het ochtendvoer was energetisch gelijk aan het controlevoer, maar het bevatte meer eiwit en fosfor ( $P$ ) en minder calcium (Ca) (Bijlage 2). Het middagvoer had een lager gehalte aan energie, eiwit en $P$ en een hoger gehalte Ca t.o.v. het controlevoer en het ochtendvoer. De dieren kregen een vooraf bepaalde voerhoeveelheid verstrekt zodat alle dieren van de verschillende behandelingen hetzelfde gewichtsschema volgden (Aviagen-EPI, 2017). 


\begin{tabular}{lllll} 
Behandeling & Code & Voersoort & Voerfrequentie \\
A & CON1x & Controlevoer (standaard foktoomvoer 3) & Eenmaal per dag \\
\hline B & CON2x & Controlevoer (standaard foktoomvoer 3) & Tweemaal per dag \\
\hline C & SP2x & Split-feeding (speciaal ochtend- en middagvoer) & Tweemaal per dag \\
\hline
\end{tabular}

\subsection{Waarnemingen}

\subsubsection{Analyses in grondstoffen en voeders}

Voor aanvang van het definitief formuleren en produceren van de experimentele voeders werden de gehaltes bepaald van de zes belangrijkste grondstoffen (tarwe, mais, zonnebloemschroot, sojaschroot, raapzaadschroot en raapzaadschilfers). Het betrof de gehaltes aan droge stof (vocht), ruw eiwit, ruw vet, ruwe celstof, ruw as, zetmeel, suikers, Ca en P. Deze gehaltes werden ook bepaald in de uiteindelijke proefvoeders.

\subsubsection{Lichaamsgewicht hennen en hanen}

Voor aanvang van het experiment op 50 weken leeftijd werden alle hennen per hok gewogen (groepsweging). Tijdens het experiment werd eenmaal per twee weken het gemiddelde lichaamsgewicht per hok vastgesteld door een steekproef van 10 dieren per hok te wegen (groepsweging). Daarnaast werden de aanwezige hanen gewogen.

\subsubsection{Productie resultaten}

Gedurende het experiment werden de volgende productieresultaten verzameld: voer- en wateropname, uitval, eiproductie en -gewicht en uitsortering tweede soort eieren. Tweemaal per week werden de dagporties voer voor de betreffende behandelingen afgewogen. De wateropname werd bepaald door de hoogte van de waterstand (om de dag voordat het licht uitging) in het voorraadvat per hok te noteren. Het voorraadvat voor het water werd daarna aangevuld tot 25 liter waarna de wekelijkse wateropname werd berekend. Dagelijks werd het aantal eieren per hok bijgehouden, waarbij onderscheid werd gemaakt tussen $1^{\mathrm{e}}$ en $2^{\mathrm{e}}$ soort broedeieren. Tweede soort eieren werden onderverdeeld in: ei < 50 gram, dubbeldooier, breuk/kneus/wind of vuil ei. Grondeieren werden apart genoteerd. Op vrijdag werden alle broedeieren van die dag gewogen. Uitval en uitvaloorzaak werd indien aangetroffen genoteerd.

\subsubsection{Broederijresultaten}

Op 55 en 60 weken leeftijd werden 50 broedeieren per hok verzameld en zeven dagen bebroed in een HatchTech Microclimer 150 om de bevruchting en embryonale sterfte na zeven dagen te bepalen. Tijdens de break-out werden de eieren handmatig opengebroken en vervolgens beoordeeld of het ei bevrucht was en in welke fase van ontwikkeling het embryo zich bevond. Tevens werd d.m.v. een scoreformulier de volgende parameter bijgehouden: haarscheurtjes, positie van het embryo, abnormaal embryo, afgestorven embryo op dag 1, dag 2, dag 3-4 en dag 5 (Warin, 2009).

\subsubsection{Broedeikwaliteit}

\section{Eischaaldikte}

Op 56 en 59 weken leeftijd werden tien $1^{\text {e }}$ soort broedeieren per hok verzameld en getest op eischaaldikte. De schaaldikte van de eieren werd bepaald op drie plaatsen van het ei: de bovenkant, het midden en de onderkant (van Krimpen et al., 2018). Daarvoor werden stukjes schaal gebruikt van enkele vierkante millimeters oppervlakte, zodat de bolling van de schaal zo klein mogelijk werd. Ook werd het binnenste schaalmembraan van de schaal verwijderd. Met behulp van een Mitutoyo 395-541 (Figuur 2.3) werd de schaaldikte van de afzonderlijke stukjes eischaal bepaald. Hieruit werd vervolgens de gemiddelde eischaaldikte per individueel ei berekend. 


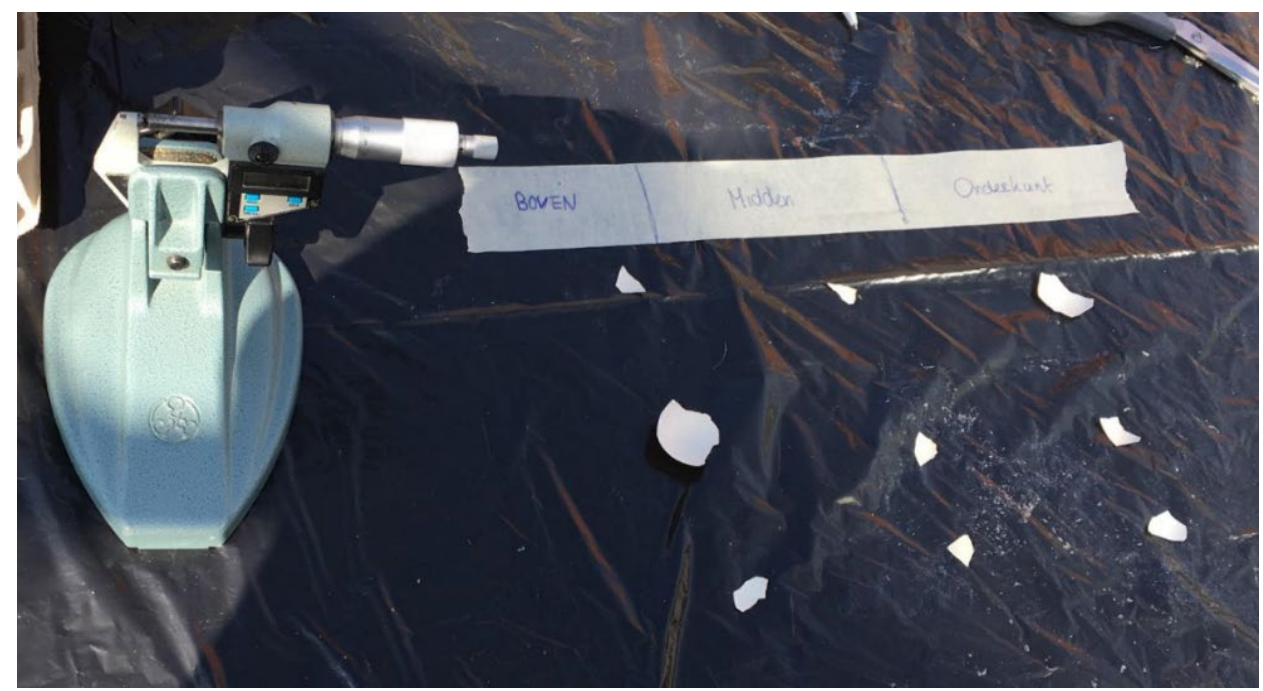

Figuur 2.3 Meting van de eischaaldikte (top, midden en onderkant van ei).

\section{Breuksterkte}

Op 56 en 59 weken leeftijd werd de maximale breuksterkte en de stijfheid (een maat voor de flexibiliteit) van de eischaal bepaald bij tien $1^{\mathrm{e}}$ soort eieren per hok. Hiervoor werd gebruik gemaakt van een Instron 5564 Texture Analyzer (Figuur 2.4) (Norwood, Massachusetts, VS). De eieren werden in een plastic bakje met een stukje kartonnen eiertray geplaatst, zodat ze rechtop bleven staan, en alle eieren op hetzelfde punt werden getest. Het apparaat bepaalde daarna bij ieder ei afzonderlijk de compressiedruk bij breuk (Newton), energie tot breuk (J) en de ei-stijfheid (N/mm).

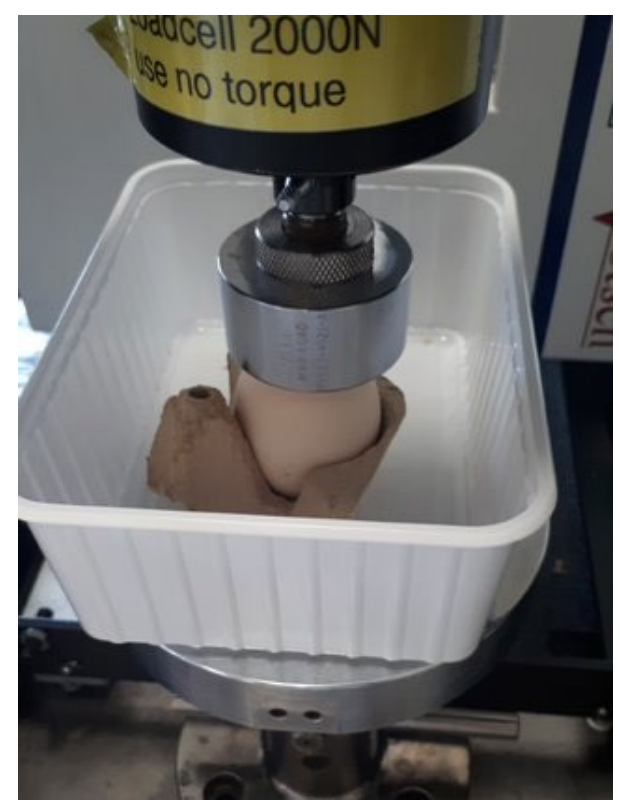

Figuur 2.4 Meting van de breuksterkte.

\section{Egg mottling}

Op 56 en 59 weken leeftijd werden 30 broedeieren per hok verzameld. Deze werden gescoord op 'egg mottling', waarbij de volgende scores werden gegeven: 4 (extreem), 3 (veel), 2 (weinig) tot 1 (gering) (Figuur 2.5) (Hebbink, 2018). Egg mottling is een maat voor de aanwezigheid van doorschijnende vlekken die ontstaan doordat de synthese van de eiwitmatrix in de eischaal onder invloed van stress en/of ziekte niet optimaal is. Uit onderzoek van Hebbink (2018) bleek dat een meer 'egg mottling' resulteert in meer gewichtsverschil op dag 18 van het broedproces en een lagere uitkomst van bevruchte eieren. 


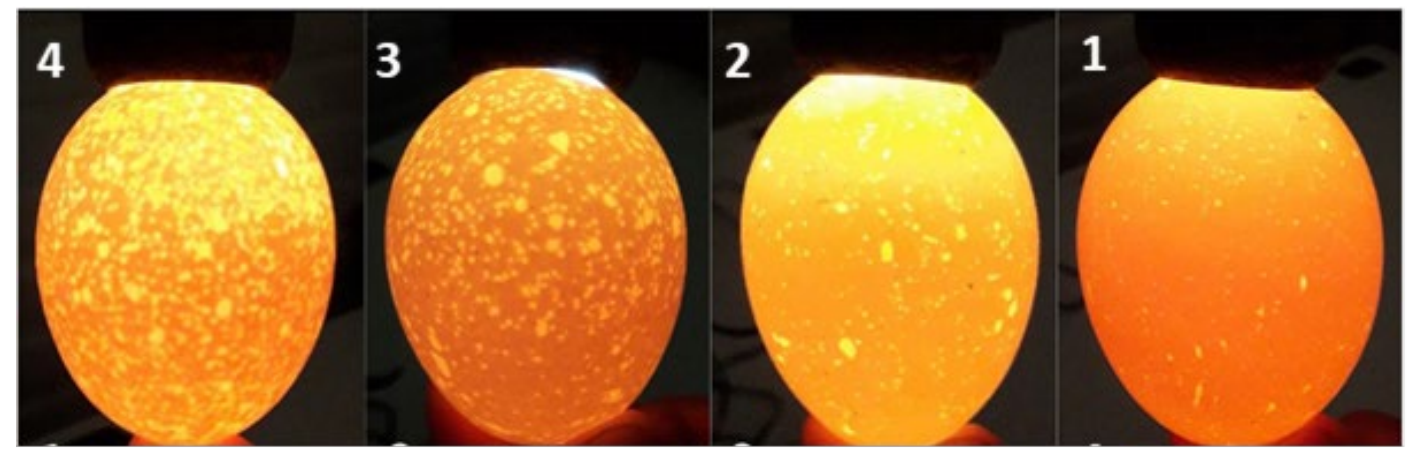

Figuur 2.5 Scores egg mottling van 4 (extreem) naar 1 (gering).

\section{Albumen/dooier verhouding en schaalgewicht}

Op 51, 53 en 56 weken leeftijd werden 10 broedeieren per hok verzameld en werd de albumen/dooier verhouding bepaald. De eieren werden eerst vers gewogen en daarna in 10 minuten hardgekookt. De hardgekookte eieren werden weer gewogen en vervolgens werden de schaal, dooier en het albumen gescheiden en gewogen. Uit deze afzonderlijke gewichten is de verhouding tussen albumen en dooier berekend ten opzichte van het gehele eigewicht en van elkaar.

De schaalgewichten werden direct na koken en na 24 uur drogen bij kamertemperatuur bepaald. Door het drogen was het aanwezige water in de schalen verdampt en kon ook het percentage droge stof in de eischaal worden bepaald.

\subsubsection{Gedrag}

Op 54 en 59 weken leeftijd werd door 2 personen gedragsonderzoek uitgevoerd (van Emous et al., 2015). Het gedrag van de dieren werd per hok achtmaal per waarnemingsdag gemeten met behulp van scan sampling (ethogram in Bijlage 3). Hierbij liepen de onderzoekers langs de hokken en werd genoteerd welk gedrag elk individueel dier uitvoerde. Na het observeren van het gedrag werd genoteerd waar de dieren zich in het hok bevonden. De gedragingen werden weergegeven als percentage van het totaal aantal dieren dat het gedrag uitvoerde op dat moment in dat hok.

\subsubsection{Bevedering}

Tijdens de experimentele periode werd tweemaal (week 55 en week 60) de kwaliteit van het verenpakket van 6 dieren/hok beoordeeld volgens de methode van Bilcik en Keeling (1999). Er werd gescoord op 7 onderdelen van het lichaam (nek, borst, buik, rug, vleugels, staart, dijbeen) en er werden scores gegeven tussen 0 (gaaf) tot 5 (kaal).

\subsection{Statistische analyse}

Hok was de experimentele eenheid en de data werd geanalyseerd m.b.v. Genstat 19 (2018) software. De $P$-waarde van het behandelingseffect en de LSD (kleinste significante verschil $(P<0,05)$ ) worden per responsparameter weergegeven. Behandelingseffecten met een $P$-waarde $<0,05$ worden als statistisch significant beschouwd. Een tendens tot een verschil werd beschouwd bij een $P$-waarde 0,05 $<P<0,10$. Responsparameters werden geanalyseerd met behulp van ANOVA (variantieanalyses) volgens het volgende model: $Y_{i j}=\mu+$ Blok $_{i}+$ voerstrategie $_{j}+$ Error $_{i j}$ met $Y$ als respons pararmeter, $\mu$ als algemeen gemiddelde, blok als effect van de twee afdelingen $(i=1,2)$, voerstrategie als effect van de voerstrategie $(j=1 . . .3)$ en Error als de Error term.

Het statistische model voor broederijresultaten, eischaalkwaliteit, gedrag en bevedering bevatte ook

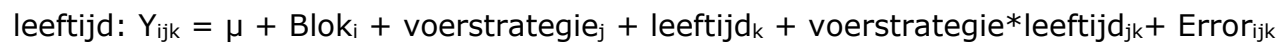

Met: $Y$ als respons pararmeter, $\mu$ als algemeen gemiddelde, blok $=$ afdelingseffect $(i=1,2)$, voerstrategie $(j=1 \ldots 3)$, leeftijd $(k=1,2)$ en Error als de Error term. 


\section{Resultaten}

\subsection{Verloop experiment}

Het experiment met split-feeding en twice a day-feeding is zonder verstoringen verlopen. De dieren waren gezond en ze produceerden tussen 50 en 60 weken leeftijd ver boven de norm, gemiddeld 51,5 totaal eieren terwijl 39,2 stuks door de fokkerijorganisatie als norm wordt gegeven. De gemiddelde dagproductie was 73,8 terwijl $60,2 \%$ de norm is. Het productiegetal (weeknummer plus leg\%) was met gemiddeld 129,3 erg hoog t.o.v. de gemiddelde norm van 115,7. De hoge productie van de dieren werd mede veroorzaakt doordat de dieren 2,5 week te laat in productie kwamen, doordat de afdelingen tijdens de opfokperiode niet volledig donker waren. Hierdoor produceerden de dieren tot 30 weken leeftijd onder de norm (18 t.o.v. de norm van 33 eieren) terwijl ze tussen 30 en 50 weken leeftijd boven de norm produceerden. Verder was de uitval in deze experimentele periode (50-60 weken leeftijd) laag, met 0,7\%, t.o.v. de norm van 2,0\%. De hoge productie en lage uitval werd mede veroorzaakt doordat de aantallen dieren per hok op 50 weken leeftijd zijn teruggebracht naar 24 stuks. Hierdoor werden de slechtere en niet (goed) productieve dieren uitgeselecteerd.

\subsection{Analyse voeders}

Het geanalyseerde ruw eiwitgehalte van het controle, ochtend- en middagvoer lag respectievelijk 3,4, 5,7 en $1,2 \%$ (gemiddeld 3,4\%) hoger dan de berekende gehalten (Tabel 2). Doordat de geanalyseerde gehalten voor alle voeders hoger was, bleef het gewenste contrast tussen de voeders aanwezig. Het geanalyseerde ruw vetgehalte was wat lager voor het controle- $(-4,3 \%)$ en middagvoer $(-2,2 \%)$ en hoger voor het ochtendvoer $(+2,1 \%)$. Het geanalyseerde zetmeelgehalte lag voor alle voeders wat lager dan de berekende gehalten. Het geanalyseerde calciumgehalte vertoonde wat grotere afwijkingen (respectievelijk $+10,0,-5,2$ en $+19,6 \%$ voor het controle, ochtend- en middagvoer) wat veroorzaakt werd door de beschikbaarheid van gereserveerde grondstoffen Het beoogde contrast tussen de voeders was echter duidelijk aanwezig in de voeders met, t.o.v. het controle voer, een lager calciumgehalte in het ochtendvoer en hoger gehalte in het middagvoer. Het geanalyseerde fosforgehalte was voor alle voeders flink hoger (gemiddeld 10,7\%) dan het berekende gehalten, maar ook hier bleef het gewenste contrast tussen de verschillende voeders in stand.

Tabel 2 Berekende en geanalyseerde gehalten proefvoeders $(\mathrm{g} / \mathrm{kg})$.

\begin{tabular}{|c|c|c|c|c|c|c|}
\hline \multirow[t]{2}{*}{ Nutriënt } & \multicolumn{2}{|c|}{ Controle voer } & \multicolumn{2}{|c|}{ Ochtendvoer } & \multicolumn{2}{|c|}{ Middagvoer } \\
\hline & Berekend & Analyse & Berekend & Analyse & Berekend & Analyse \\
\hline Droge stof & 898 & 890 & 896 & 887 & 900 & 894 \\
\hline Ruw eiwit & 133,5 & 138,0 & 140,0 & 148,0 & 127,5 & 129,0 \\
\hline Ruw vet & 49,1 & 47,0 & 47,0 & 48,0 & 45,0 & 44,0 \\
\hline Ruwe celstof & 45,0 & 43,0 & 47,0 & 51,0 & 43,0 & 39,0 \\
\hline Ruw as & 110,8 & 108,0 & 98,0 & 87,0 & 136,1 & 142,0 \\
\hline Zetmeel & 430,6 & 421 & 430,2 & 425 & 423,8 & 417 \\
\hline Calcium & 34,0 & 37,4 & 28,7 & 27,2 & 44,5 & 53,2 \\
\hline Fosfor & 4,16 & 4,43 & 4,24 & 4,92 & 3,61 & 3,96 \\
\hline
\end{tabular}

\subsection{Lichaamsgewicht hennen en hanen}

Het lichaamsgewicht van de hennen was gedurende het experiment onderling niet verschillend (Figuur 3.1). De hanen die bij de SP2x hennen werden gehouden waren gedurende het gehele experiment circa 500 gram significant lichter dan de hanen die bij de CON2x hennen werden gehouden. De hanen die bij de CON1x hennen werden gehouden lagen er tussen in. 


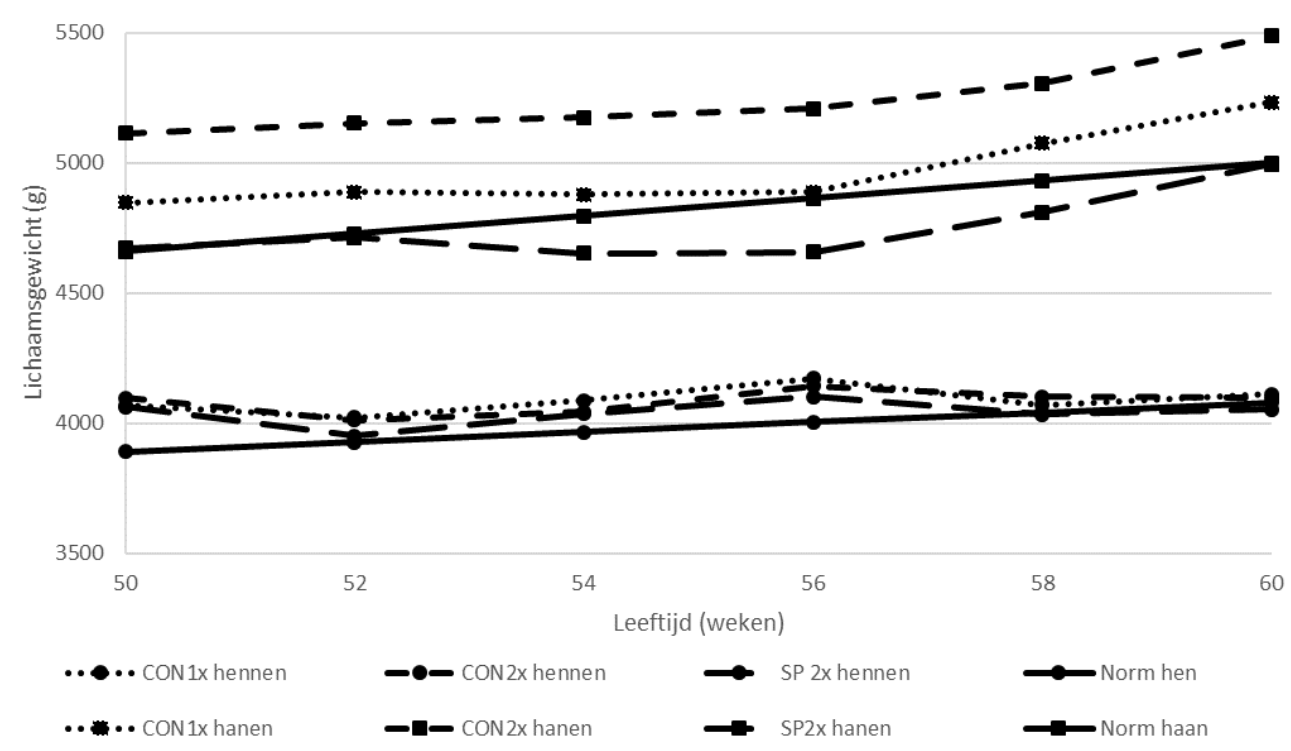

Figuur 3.1 Ontwikkeling lichaamsgewicht hennen en hanen gedurende het experiment.

\subsection{Productieresultaten}

Er werden geen verschillen in water opname en water/voer-verhouding aangetroffen (Tabel 3). De water/voer-verhouding was gemiddeld 1,93.

Tabel 3 Gemiddelde voergift hennen per behandeling, gemiddelde voergift hanen en effect van de verschillende voerstrategieën op wateropname en water/voer-verhouding (51-60 weken).

\begin{tabular}{|c|c|c|c|c|}
\hline Voer strategie ${ }^{1}$ & $\begin{array}{l}\text { Voergift hennen } \\
\qquad(\mathrm{g} / \mathrm{d} / \mathrm{d})\end{array}$ & $\begin{array}{l}\text { Voergift hanen } \\
\qquad(\mathrm{g} / \mathrm{d} / \mathrm{d})\end{array}$ & $\begin{array}{l}\text { Water opname } \\
(\mathrm{ml} / \mathrm{d} / \mathrm{d})\end{array}$ & $\begin{array}{l}\text { Water/voer - } \\
\text { verhouding }\end{array}$ \\
\hline CON1x & 157,4 & 153,0 & 305,0 & 1,94 \\
\hline $\operatorname{con} 2 x$ & 157,4 & 153,0 & 298,6 & 1,90 \\
\hline SP2x & 157,8 & 153,0 & 307,1 & 1,95 \\
\hline SEM & & & 3,5 & 0,02 \\
\hline$P$-waarde & & & 0,22 & 0,26 \\
\hline
\end{tabular}

De SP2x dieren neigden naar een hoger legpercentage tussen 51 en 55 weken leeftijd t.o.v. de CON1x dieren terwijl de CON2x dieren er tussen in zaten $(P=0,088$; Tabel 4$)$. Doordat er geen significant verschil in productie was tussen 56 en 60 weken leeftijd was er ook geen verschil in productie over de gehele experimentele periode (51-60 weken). Voor de andere productieresultaten werden geen verschillen gevonden.

Tabel 4 Effecten van de verschillende voerstrategieën op de productieresultaten.

\begin{tabular}{|c|c|c|c|c|c|c|c|c|}
\hline $\begin{array}{l}\text { Voer } \\
\text { strategie }^{1}\end{array}$ & $\begin{array}{c}\operatorname{Leg} \% \\
(51-55 \\
\text { wk) }\end{array}$ & $\begin{array}{c}\text { Leg } \% \\
(56-60 \\
w k)\end{array}$ & $\begin{array}{c}\text { Leg } \% \\
(51-60 \\
\text { wk) }\end{array}$ & $\begin{array}{c}\text { BE }(\%) \\
(51-60 \\
w k)^{2}\end{array}$ & $\begin{array}{c}\text { BKW }(\%) \\
(51-60 \\
w k)^{3}\end{array}$ & $\begin{array}{c}\text { Vuil\% } \\
(51-60 \\
\text { wk) }\end{array}$ & $\begin{array}{l}\text { Grond\% } \\
\begin{array}{c}(51-60 \\
w k)^{5}\end{array}\end{array}$ & $\begin{array}{c}\text { Gem. ei } \\
\text { gewicht } \\
\text { (g) }\end{array}$ \\
\hline CON1x & $74,0^{(a)}$ & 70,0 & 72,0 & 62,4 & 2,9 & 8,9 & 1,7 & 66,9 \\
\hline $\operatorname{con} 2 x$ & $76,1^{(a b)}$ & 72,5 & 74,3 & 65,1 & 2,2 & 6,2 & 3,7 & 67,0 \\
\hline SP2x & $77,2^{(b)}$ & 73,1 & 75,1 & 64,8 & 2,1 & 7,9 & 3,7 & 66,6 \\
\hline SEM & 1,0 & 1,4 & 1,1 & 1,5 & 0,5 & 1,0 & 1,0 & 0,3 \\
\hline$P$-waarde & 0,088 & 0,26 & 0,13 & 0,31 & 0,45 & 0,21 & 0,26 & 0,65 \\
\hline \multicolumn{9}{|c|}{$\begin{array}{l}{ }^{1} \mathrm{CON} 1 \mathrm{x}=\text { controle voer eenmaal/dag, CON2x }=\text { controle voer tweemaal } / \mathrm{dag}, \mathrm{SP} 2 \mathrm{x}=\text { split-feeding tweemaal/dag } \\
{ }^{2} \mathrm{BE} \%=\text { percentage productie aan broedeieren. }\end{array}$} \\
\hline
\end{tabular}




\subsection{Broederijresultaten}

De verschillende voerstrategieën hadden geen effect op de diverse broederijresultaten (Tabel 5). De embryonale sterfte op dag 3-4 was significant verschillend tussen hennen van 55 en 60 weken leeftijd. Deze was lager voor de broedeieren op 60 weken leeftijd $(P=0,021)$ en door dit verschil, was ook de totale embryonale sterfte lager op 60 weken leeftijd $(P=0,019)$.

Tabel 5 Effecten van de verschillende voerstrategieën en leeftijden op de broederijresultaten.

\begin{tabular}{|c|c|c|c|c|c|}
\hline Behandeling ${ }^{1}$ & $\begin{array}{c}\text { Bevruchting } \\
(\%)\end{array}$ & $\begin{array}{c}\text { Embryonale } \\
\text { sterfte D2 } \\
(\%)\end{array}$ & $\begin{array}{c}\text { Embryonale } \\
\text { sterfte D3-4 } \\
(\%)\end{array}$ & $\begin{array}{c}\text { Embryonale } \\
\text { sterfte D5 } \\
(\%)\end{array}$ & $\begin{array}{c}\text { Totale } \\
\text { embryonale } \\
\text { sterfte (\%) }\end{array}$ \\
\hline \multicolumn{6}{|l|}{ Voerstrategie $^{1}$} \\
\hline CON1x & 94,9 & 0,1 & 1,9 & 0,3 & 2,3 \\
\hline $\operatorname{CON} 2 x$ & 95,5 & 0,0 & 1,9 & 0,0 & 1,9 \\
\hline $\mathrm{SP} 2 \mathrm{x}$ & 97,6 & 0,7 & 1,8 & 0,0 & 2,4 \\
\hline SEM & 1,1 & 0,2 & 0,5 & 0,1 & 0,5 \\
\hline \multicolumn{6}{|l|}{ Leeftijd } \\
\hline $55 \mathrm{wk}$ & 95,9 & 0,2 & $1,1^{\mathrm{b}}$ & 0,1 & $1,3^{b}$ \\
\hline $60 \mathrm{wk}$ & 96,1 & 0,4 & $0,3^{a}$ & 0,1 & $3,0^{\mathrm{a}}$ \\
\hline SEM & 0,9 & 0,1 & 0,4 & 0,1 & 0,3 \\
\hline \multicolumn{6}{|l|}{$P$-waarde } \\
\hline Voerstrategie & 0,16 & 0,12 & 0,98 & 0,11 & 0,78 \\
\hline Leeftijd & 0,85 & 0,31 & 0,021 & 0,93 & 0,019 \\
\hline Voerstr*Leeftijd & 0,31 & 0,76 & 0,85 & 0,99 & 0,92 \\
\hline
\end{tabular}

\subsection{Broedeikwaliteit}

Er werden geen effecten van de voerstrategieën op de broedeikwaliteit aangetroffen (Tabel 6). De leeftijd had wel enig effect op de broedeikwaliteit. De broedeieren op 59 weken leeftijd hadden een iets dunnere schaal $(0,330$ vs. 0,336 mm; $P=0,004)$ dan de eieren op 56 weken leeftijd. Verder neigden de eieren van hennen op 59 weken leeftijd tot een hogere egg mottling dan de eieren van hennen op 56 weken leeftijd $(P=0.077)$.

Tabel 6 Effecten van de verschillende voerstrategieën en leeftijden op schaaldikte, breuksterkte en egg mottling.

\begin{tabular}{|c|c|c|c|c|c|}
\hline Behandeling & Schaaldikte (mm) & $\begin{array}{l}\text { Compressie } \\
\text { (N/mm) tot } \\
\text { breuk }\end{array}$ & $\begin{array}{l}\text { Energie } \\
\text { (Joule) tot } \\
\text { breuk }\end{array}$ & $\begin{array}{c}\text { Breuksterkte } \\
\text { (Newton) }\end{array}$ & Egg mottling \\
\hline \multicolumn{6}{|l|}{ Voerstrategie $^{1}$} \\
\hline CON1x & 0,337 & 1,50 & 0,0156 & 39,0 & 1,53 \\
\hline $\operatorname{con} 2 x$ & 0,331 & 1,50 & 0,0155 & 37,8 & 1,53 \\
\hline $\mathrm{SP} 2 \mathrm{x}$ & 0,331 & 1,49 & 0,0156 & 37,8 & 1,53 \\
\hline SEM & 0,003 & 0,03 & 0,0006 & 0,7 & 0,05 \\
\hline \multicolumn{6}{|l|}{ Leeftijd } \\
\hline 56 wk & $0,336^{a}$ & 1,48 & 0,0153 & 38,3 & $1,48^{(b)}$ \\
\hline $59 w k$ & $0,330^{\mathrm{b}}$ & 1,51 & 0,0159 & 38,1 & $1,58^{(a)}$ \\
\hline SEM & 0,001 & 0,02 & 0,0004 & 0,5 & 0,04 \\
\hline \multicolumn{6}{|l|}{$P$-waarde } \\
\hline Voerstrategie & 0,19 & 0,93 & 0,99 & 0,39 & 0,99 \\
\hline Leeftijd & 0,004 & 0,42 & 0,32 & 0,75 & 0,077 \\
\hline Voerstr*Leeftijd & 0,086 & 0,67 & 0,33 & 0,58 & 0,55 \\
\hline
\end{tabular}


Er werden geen effecten van de behandelingen waargenomen op het schaalgewicht (na koken), schaalgewicht na 24 uur drogen, droge stofgehalte schaal en albumen/dooier verhouding (Tabel 7). Wel was er een leeftijdseffect tot een lagere albumen/dooier verhouding op 56 t.o.v. 51 en 53 weken leeftijd $(P=0,013)$.

Tabel 7 Effecten van de verschillende voerstrategieën en leeftijden op schaalgewicht (na koken), schaalgewicht na 24 uur drogen, droge stofgehalte schaal en albumen/dooier verhouding.

\begin{tabular}{|c|c|c|c|c|}
\hline Behandeling ${ }^{1}$ & $\begin{array}{c}\text { Schaalgewicht na } \\
\text { koken (g) }\end{array}$ & $\begin{array}{l}\text { Schaalgewicht na } \\
24 \text { uur drogen (g) }\end{array}$ & $\begin{array}{c}\text { Droge stofgehalte } \\
\text { schaal }(\%)\end{array}$ & $\begin{array}{c}\text { Albumen/dooier } \\
\text { verhouding }\end{array}$ \\
\hline \multicolumn{5}{|l|}{ Voerstrategie $^{1}$} \\
\hline Con1x & 6,81 & 6,08 & 89,2 & 1,77 \\
\hline $\operatorname{con} 2 x$ & 6,78 & 6,07 & 89,5 & 1,78 \\
\hline SP $2 x$ & 6,70 & 6,01 & 89,3 & 1,74 \\
\hline SEM & 0,05 & 0,04 & 0,3 & 0,02 \\
\hline \multicolumn{5}{|l|}{ Leeftijd } \\
\hline $51 \mathrm{wk}$ & 6,75 & 6,03 & 89,0 & $1,78^{\mathrm{a}}$ \\
\hline 53 wk & 6,70 & 6,01 & 89,7 & $1,78^{\mathrm{a}}$ \\
\hline 56 wk & 6,84 & 6,12 & 89,3 & $1,73^{\mathrm{b}}$ \\
\hline SEM & 0,05 & 0,04 & 0,4 & 0,01 \\
\hline \multicolumn{5}{|l|}{$P$-waarde } \\
\hline Voerstrategie & 0,25 & 0,45 & 0,83 & 0,17 \\
\hline Leeftijd & 0,11 & 0,14 & 0,43 & 0,013 \\
\hline Voerstr*Leeftijd & 0,70 & 0,53 & 0,71 & 0,91 \\
\hline
\end{tabular}

\subsection{Gedrag}

De tweemaal per dag gevoerde dieren (CON2x en SP2x) vertoonden gemiddeld gedurende de dag meer eetgedrag (respectievelijk $33,5 \%$ en $33,6 \%$ vs. 30,9\%; $P=0,040$ ) dan de CON1x dieren (Tabel 8). Verder was er een tendens tot een meer zitgedrag bij de SP2x dieren $(9,1 \%$ vs. 5,7\%; P = 0,070) t.o.v. de CON1x dieren, terwijl de CON2x er tussen in zaten. De tweemaal per dag gevoerde dieren (CON2x en SP2x) vertoonden daarentegen minder foerageergedrag (respectievelijk 11,2\% en 10,0\% vs. $16,7 \%$; $P<0,001$ ) en objectpik gedrag (respectievelijk $0,4 \%$ en $0,5 \%$ vs. $1,4 \%$; $P=0,003$ ). Daarnaast werden diverse leeftijd gerelateerde significante verschillen aangetroffen op het gedrag van de dieren. De dieren vertoonden op 59 t.o.v. 54 weken leeftijd minder eet- en drinkgedrag, en meer staan, lopen, foerageren, comfort en kip pikken gedrag.

Er was een tendens tot meer dieren op het strooisel voor de tweemaal per dag gevoerde dieren (CON2x en SP2x) t.o.v. de eenmaal per dag gevoerde dieren (CON1x) (respectievelijk 82,4\% en $82,2 \%$ vs. $80,0 \% ; P=0,093$ ). De dieren die tweemaal per dag gevoerd werden (CON2x en SP2x) waren minder op het rooster aanwezig (respectievelijk 14,9\% en $14,7 \%$ vs. $17,0 \%$; P = 0,010). Op 59 weken leeftijd waren er meer dieren op het strooisel $(84,4 \%$ vs. $78,7 \%$; $P<0,001)$ en minder op het rooster $(12,7 \%$ vs. $18,4 \% ; \mathrm{P}<0,001)$ dan op 54 weken leeftijd. 
Tabel 8

Effecten van de verschillende voerstrategieën en leeftijden op gedrag en plaats in het hok.

\begin{tabular}{|c|c|c|c|c|c|c|c|c|c|c|c|c|c|c|c|}
\hline Behandeling ${ }^{1}$ & Eten & Drinken & Staan & Zitten & Lopen & $\begin{array}{l}\text { Foera- } \\
\text { geren }\end{array}$ & Comfort & Stofbad & $\begin{array}{l}\text { Object } \\
\text { pikken }\end{array}$ & $\begin{array}{c}\text { Kip } \\
\text { pikken }\end{array}$ & Ei leggen & Overig & $\begin{array}{c}\text { Strooisel } \\
(\%)\end{array}$ & $\begin{array}{c}\text { Rooster } \\
(\%)\end{array}$ & $\begin{array}{c}\text { Zitstok } \\
(\%)\end{array}$ \\
\hline \multicolumn{16}{|l|}{ Voerstrategie $^{1}$} \\
\hline Con1x & $30,9^{b}$ & 13,9 & 13,2 & $5,7^{(\mathrm{b})}$ & 8,6 & $16,7^{\mathrm{a}}$ & 6,8 & 1,3 & $1,4^{\mathrm{a}}$ & 1,0 & 0,1 & 0,4 & $80,0^{(b)}$ & $17,0^{\mathrm{a}}$ & 3,0 \\
\hline $\operatorname{con} 2 x$ & $33,5^{a}$ & 12,3 & 17,0 & $8,0^{(a b)}$ & 7,9 & $11,2^{\mathrm{b}}$ & 6,8 & 2,0 & $0,4^{b}$ & 0,6 & 0,1 & 0,3 & $82,4^{(a)}$ & $14,9^{\mathrm{b}}$ & 2,7 \\
\hline SP2x & $33,6^{a}$ & 13,0 & 16,5 & $9,1^{(a)}$ & 7,8 & $10,0^{\mathrm{b}}$ & 7,0 & 1,2 & $0,5^{b}$ & 0,8 & 0,1 & 0,3 & $82,2^{(a)}$ & $14,7^{b}$ & 3,1 \\
\hline SEM & 0,8 & 0,7 & 1,4 & 1,0 & 0,5 & 0,7 & 0,7 & 0,3 & 0,2 & 0,2 & 0,0 & 0,1 & 0,8 & 0,5 & 0,6 \\
\hline \multicolumn{16}{|l|}{ Leeftijd } \\
\hline $54 \mathrm{wk}$ & $34,4^{a}$ & $15,5^{\mathrm{a}}$ & $14,6^{\mathrm{b}}$ & 7,2 & $7,2^{\mathrm{b}}$ & $11,5^{\mathrm{b}}$ & $6,2^{\mathrm{b}}$ & 1,5 & 0,9 & $0,5^{b}$ & 0,1 & 0,3 & $78,7^{\mathrm{b}}$ & $18,4^{\mathrm{a}}$ & 3,0 \\
\hline $59 \mathrm{wk}$ & $30,9^{\mathrm{b}}$ & $10,6^{\mathrm{b}}$ & $16,6^{\mathrm{a}}$ & 8,1 & $9,0^{a}$ & $13,7^{\mathrm{a}}$ & $7,5^{\mathrm{a}}$ & 1,5 & 0,6 & $1,1^{\mathrm{a}}$ & 0,1 & 0,3 & $84,4^{\mathrm{a}}$ & $12,7^{\mathrm{b}}$ & 2,9 \\
\hline SEM & 0,5 & 0,4 & 0,7 & 0,6 & 0,4 & 0,5 & 0,4 & 0,3 & 0,2 & 0,1 & 0,0 & 0,1 & 0,5 & 0,4 & 0,3 \\
\hline \multicolumn{16}{|l|}{$P$-waarde } \\
\hline Voerstrategie & 0,040 & 0,26 & 0,15 & 0,070 & 0,52 & $<0,001$ & 0,98 & 0,27 & 0,003 & 0,34 & 0,85 & 0,83 & 0,093 & 0,010 & 0,84 \\
\hline Leeftijd & 0,001 & $<0,001$ & 0,038 & 0,25 & $<0,001$ & 0,003 & 0,031 & 0,91 & 0,17 & 0,002 & 0,72 & 0,84 & $<0,001$ & $<0,001$ & 0,91 \\
\hline Voerstr*Leeftijd & 0,64 & 0,37 & 0,84 & 0,52 & 0,44 & 0,63 & 0,69 & 0,73 & 0,16 & 0,37 & 0,36 & 0,55 & 0,79 & 0,69 & 0,45 \\
\hline
\end{tabular}

${ }^{1}$ CON1x $=$ controle voer eenmaal/dag, CON2x = controle voer tweemaal/dag, SP2x = split-feeding tweemaal/dag

$a, b$ Verschillende letters geven een significant verschil aan $P \leq 0,05$ )

$(a, b)$ Verschillende letters tussen haakjes geven een tendens tot een verschil aan $(0,05<P<0,10)$. 
In Figuur 3.2 zijn de verschillende soorten gedrag (eten, drinken, staan, zitten, lopen, foerageren, comfort, stofbad, object pikken en kip pikken) gedurende de dag grafisch weergegeven.
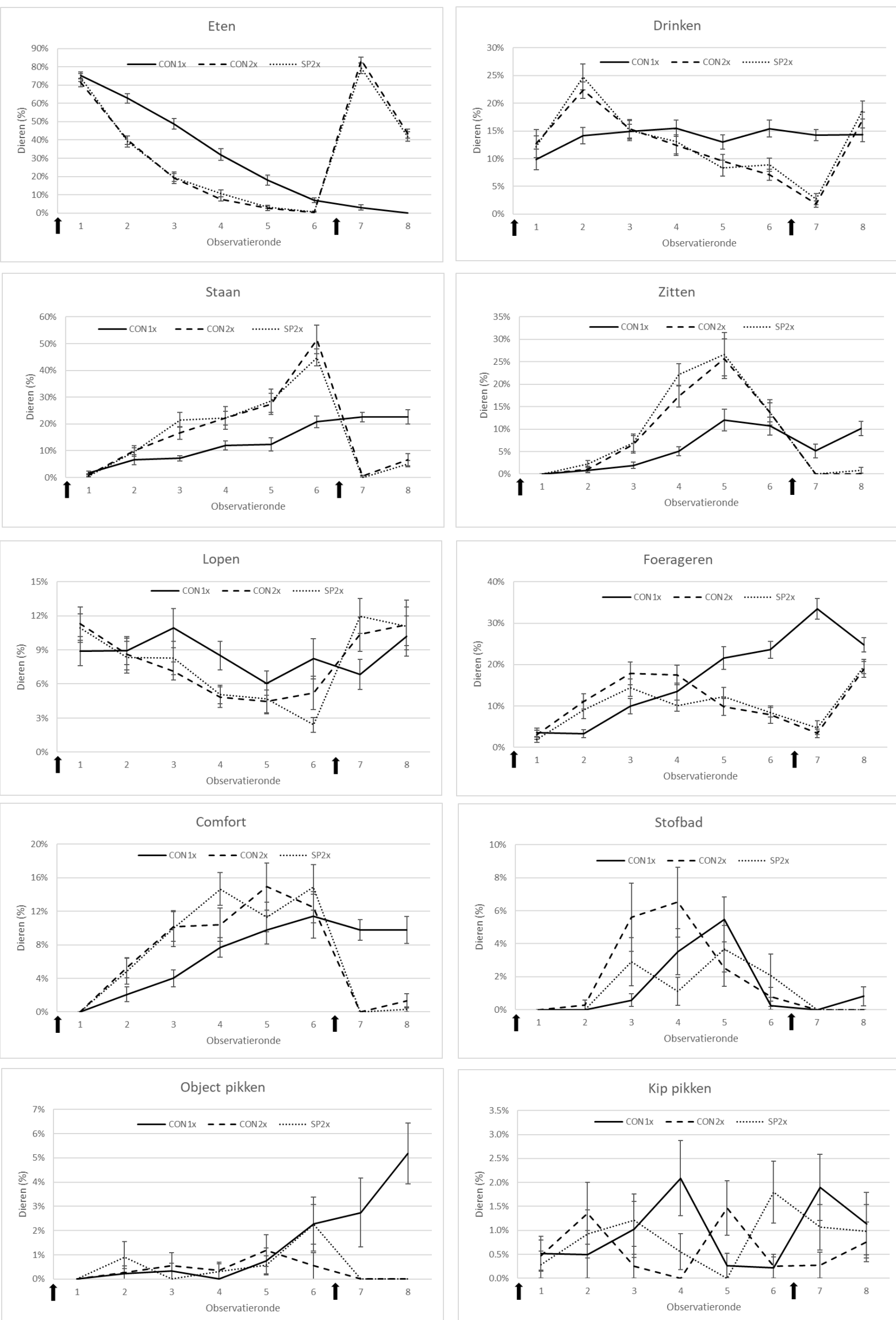

Figuur 3.2 Effect van voerstrategie op ontwikkeling verschillende gedragingen gedurende de dag. Pijlen geven het moment van voeren aan (1 $1^{e}$ 07:30 uur en $2^{e}: 14: 00$ uur). 
Er werden voor alle soorten gedrag significante interacties gevonden tussen de voerstrategie en observatieronden (Figuur 3.2). De dieren die eenmaal per dag werden gevoerd (CON1x) vertoonden een heel duidelijk ander eetpatroon dan de dieren die tweemaal per dag gevoerd (CON2x en SP2x) werden. De CON1x dieren bleven voer oppikken tot de $7^{\mathrm{e}}$ observatieronde (ca. 14:00 uur) terwijl de CON2x en SP2x dieren rond de middag geen eetgedrag meer vertoonden. De dieren die tweemaal per dag gevoerd werden begonnen vanaf de $7^{\mathrm{e}}$ observatieronde weer voer op te nemen ( $2^{\mathrm{e}}$ voerbeurt om 14:00 uur) en ruim 40\% nam nog voer op tijdens de $8^{\mathrm{e}}$ observatieronde (15:00 uur).

De CON1x dieren vertoonden een gelijkmatige wateropname gedrag gedurende de dag, terwijl de CON2x en SP2x een piek in drinken vertoonden tijdens de $2^{\mathrm{e}}$ observatieronde waarna het wateropname gedrag lineair afnam naar de $7^{\mathrm{e}}$ observatieronde om daarna tijdens de $8^{\mathrm{e}}$ observatieronde weer duidelijk toe te nemen.

De CON2x en SP2x dieren vertoonden een toenemend staangedrag gedurende de dag tot en met de $6^{e}$ observatieronde (ca. $45 \%$ van de dieren stonden) om daarna, door de $2^{\mathrm{e}}$ voerbeurt, snel af te nemen. De CON1x dieren vertoonden een langzamer lineair toenemend staan gedrag met een maximum van iets meer dan $20 \%$ van de dieren tussen de $6^{\mathrm{e}}$ en $8^{\mathrm{e}}$ observatieronde.

Het zitgedrag vertoonde min of meer hetzelfde patroon dan het staangedrag. Een snelle toename van het aantal CON2x en SP2x dieren waarbij de piek in zitgedrag echter eerder ( $5^{e}$ observatieronde) optrad gedurende de dag. De CON1x dieren vertoonden tot en met de $5^{\mathrm{e}}$ observatieronde toenemend zitgedrag om daarna rond de $10 \%$ te stabiliseren.

Het loopgedrag vertoonde een stabieler verloop voor de CON1x dieren gedurende de dag terwijl die voor de tweemaal per dag gevoerd dieren eerst een dalende trend liet om daarna weer toe te nemen. Tot en met de $4^{e}$ observatieronde werden geen verschillen tussen de voerstrategieën in foerageergedrag waargenomen. In de middag echter vertoonden de CON2x en SP2x dieren duidelijk minder foerageergedrag.

Het comfortgedrag nam voor de tweemaal per dag gevoerde dieren sneller toe en lag tot en met de $6^{e}$ observatieronde op een hoger niveau dan de eenmaal per dag gevoerde dieren. Na de tweede voerbeurt om 14:00 uur nam het comfortgedrag voor de tweemaal daags gevoerde dieren af naar bijna 0 terwijl die voor de CON1x dieren stabiel rond de $10 \%$ bleef.

De CON2x dieren vertoonden meer stofbadgedrag tijdens de $3^{e}$ en $4^{e}$ observatieronde, terwijl het daarna voor de verschillende behandelingen op een gelijk niveau lag.

Gedurende de eerste zes observatieronden werden geen verschillen tussen de voerstrategieën gevonden in het objectpikken. Tijdens de laatste 2 observatieronden ( $7^{\mathrm{e}}$ en $8^{\mathrm{e}}$ ) vertoonden de CON2x en SP2x minder objectpikken dan de CON1x dieren.

De CON1x dieren vertoonden meer pikken naar andere kippen tijdens de $4^{\mathrm{e}}$ observatieronde, terwijl de SP2x meer pikken naar andere kippen vertoonden tijdens de $6^{\mathrm{e}}$ observatieronde. 


\subsection{Bevedering}

Er werden geen effecten van de voerstrategieën op de bevedering aangetroffen (Tabel 9). De leeftijd van de hennen had enkele effecten op de scores van individuele onderdelen, echter het gemiddelde van de totale bevedering bleef hetzelfde.

Tabel 9 Effecten van de verschillende voerstrategieën en leeftijden op bevedering.

\begin{tabular}{|c|c|c|c|c|c|c|c|c|}
\hline & Nek & Borst & Buik & Rug & Vleugel & Staart & Poten & $\begin{array}{l}\text { Gem. } \\
\text { bev. }\end{array}$ \\
\hline \multicolumn{9}{|l|}{ Voerstrategie $^{1}$} \\
\hline CON1x & 2,2 & 3,1 & 2,1 & 3,1 & 2,5 & 2,9 & 2,8 & 2,7 \\
\hline $\operatorname{con} 2 x$ & 2,2 & 3,1 & 2,3 & 3,2 & 2,6 & 2,9 & 2,9 & 2,7 \\
\hline SP2x & 2,3 & 3,3 & 2,2 & 3,0 & 2,4 & 2,9 & 2,9 & 2,7 \\
\hline SEM & 0,1 & 0,1 & 0,1 & 0,1 & 0,1 & 0,1 & 0,0 & 0,1 \\
\hline \multicolumn{9}{|l|}{ Leeftijd } \\
\hline 55 wk & $2,0^{\mathrm{b}}$ & $3,2^{a}$ & 2,2 & 3,1 & $2,7^{a}$ & 2,9 & 2,9 & 2,7 \\
\hline $60 \mathrm{wk}$ & $2,4^{a}$ & $3,1^{\mathrm{b}}$ & 2,2 & 3,1 & $2,2^{b}$ & 2,9 & 2,9 & 2,7 \\
\hline SEM & 0,1 & 0,0 & 0,1 & 0,1 & 0,0 & 0,0 & 0,0 & 0,0 \\
\hline \multicolumn{9}{|l|}{$P$-waarde } \\
\hline Voerstrategie & 0,73 & 0,10 & 0,28 & 0,47 & 0,56 & 0,44 & 0,49 & 0,63 \\
\hline Leeftijd & 0,010 & 0,026 & 0,67 & 0,22 & $<0,001$ & 0,53 & 0,37 & 0,41 \\
\hline Voerstr*Leeftijd & 0,80 & 0,26 & 0,65 & 0,84 & 0,57 & 0,081 & 0,44 & 0,44 \\
\hline
\end{tabular}




\section{Discussie}

\subsection{Effect voerstrategie op productieresultaten}

De split-feeding dieren neigden tot een hogere productie $(P=0,088)$ tussen 51 en 55 weken leeftijd t.o.v. de CON1x dieren. Vergelijkbaar onderzoek met split-feeding met ouderdieren is niet voorhanden maar eerder onderzoek met twice a day-feeding laat zien dat de eiproductie hoger kan zijn (de Avila et al., 2003; Spradley et al., 2008; Taherkhani et al., 2010; Moradi et al., 2013; Soltanmoradi et al., 2013). Recentelijk is door Londero et al. (2015) aangetoond dat dieren die om 08:00 uur (100\% voer) of om 8:00 uur (50\% voer) en 15:00 uur (50\% voer) werden gevoerd een hogere productie hadden dan de dieren die om 15:00 uur (100\% voer) werden gevoerd.

In het huidige experiment werden geen verschillen in productie over de gehele legperiode $(P=0,13)$ gevonden. Dit is in overeenstemming met onderzoek van Cave (1981), Bootwalla et al. (1983), Samara et al. (1996) en Backhouse en Gous (2005) die ook geen verschillen aantroffen van verschillende voertijden en twice a day-feeding.

Er werden geen effecten van tweemaal daags voeren (twice a day-feeding en split-feeding) op het eigewicht aangetroffen wat in overeenstemming is met twice a day-feeding in het onderzoek van Samara et al. (1996) en Harms (1991). Door Cave (1981), Spradley et al. (2008) en Moradi et al. (2013) werden echter wel hogere eigewichten gevonden wanneer ouderdieren twee- of driemaal per dag gevoerd werden. In het experiment van Londero et al. (2015) hadden ouderdieren die om 15:00 uur werden gevoerd een hoger eigewicht dan kippen die om 8:00 uur werden gevoerd.

In het huidige experiment was de verwachting dat de SP2x een lager eigewicht zouden hebben. Het gemiddelde gehalte (ochtend- en avondvoer) van de belangrijkste ingrediënten voor eigewicht (methionine, cysteïne en linolzuur) was namelijk lager voor het split-feeding t.o.v. het controlevoer. Voor methionine en cysteïne was het gemiddelde gehalte namelijk 4,3\% (4,96 vs. 5,18 g/kg) lager. Voor linolzuur was die 6,7\% (15,4 vs. $16,5 \mathrm{~g} / \mathrm{kg}$ ) lager. Daarentegen was het geanalyseerde gemiddelde ruw eiwitgehalte $0,5 \%$ hoger bij de split-feeding voeders (gemiddelde van het ochtend- en middagvoer) t.o.v. het controlevoer $(138,5$ vs. $138,0 \mathrm{~g} / \mathrm{kg})$.

\subsection{Effect voerstrategie op broederijresultaten}

Er werden geen effecten van de verschillende voerstrategieën gevonden op broederijresultaten wat overeenkomt met het onderzoek van Spradley et al. (2008). Daarentegen vonden Soltanmoradi et al. (2013) dat twice a day-feeding een hogere bevruchting en uitkomst gaf. Verder vonden Londero et al. (2015) geen effecten van voeren om 08:00 uur (100\%), 09:00 en 15:00 uur (50/50\%) en 15:00 uur $(100 \%)$ op de bevruchting en uitkomst. Wel vonden zij dat dieren die om 08:00 uur de volledige voerportie verstrekt kregen een lagere embryonale sterfte hadden dan de dieren die tweemaal gevoerd werden of alleen in de middag (respectievelijk 9,3\% vs. 12,1\% en 11,8\%). Dat resulteerde bij dat onderzoek in een hogere uitkomst van de bevruchte eieren. Dit werd mogelijk veroorzaakt door het lagere eischaalgewicht en -dikte waardoor de gasuitwisseling en vochtverlies gemakkelijker verliep.

\subsection{Effect voerstrategie op broedeikwaliteit}

Er werden geen verschillen op broedeikwaliteit (\%breuk-/kneus-/windeieren, schaaldikte, breuksterkte, egg mottling, schaalgewicht en albumen/dooier verhouding) tussen de voerstrategieën aangetroffen. De verwachting voor aanvang van het onderzoek was dat split-feeding, en mogelijk ook twice a day-feeding, een verbetering van de schaalkwaliteit zou geven doordat met name het verstrekken van meer calcium in de namiddag een positief effect zou moeten hebben op de aanmaak van de eischaal. Zeker doordat het verschil in geanalyseerde gehaltes in het huidige experiment nog hoger (en verschillen dus extremer) waren. Uit het onderzoek van de Los Mozos en Sanches (2014) 
met split-feeding bij leghennen bleek namelijk dat het gewicht en dikte van de eischalen bijna 1,5\% hoger was en de dieren $30 \%$ minder breuk en windeieren produceerden.

Twice a day-feeding had ook geen effect op broedeikwaliteit in de experimenten uitgevoerd door Brake (1985), Wilson en Keeling (1991), Samara et al. (1996) en Spradley et al. (2008). Studies van Farmer et al. (1983a,b), Bootwalla et al. (1983), Backhouse en Gous (2005) en Londero et al. (2015) vonden echter dat dieren die 's middags voer verstrekt kregen de beste eischaalkwaliteit hadden.

Dat er geen verschillen in broedeikwaliteit werden aangetroffen in de huidige studie heeft mogelijk drie verschillende oorzaken:

1. Het toepassen van tweemaal daags voeren (twice a day-feeding en split-feeding) werd toegepast tussen 50 en 60 weken leeftijd. Mogelijk dat het toepassen van tweemaal daags voeren (twice a day-feeding en split-feeding) gedurende een langere periode (bv. 45 tot en met 65 weken leeftijd) meer effect heeft.

2. Tijdens het experiment kregen alle dieren wekelijks 500 gram grit verstrekt. Dit omdat de dieren in de voorgaande periode al flinke problemen met de schaalkwaliteit vertoonden (o.a. hoog aantal haarscheuren). Aan de ene kant was het gevaar van een dempend effect op de verschillen in schaalkwaliteit aanwezig door het verstrekken van extra grit, maar aan de andere kant is het verstrekken van grit in deze periode ook gebruikelijk in de praktijk. In experimenten is het belangrijk om de praktijkomstandigheden zoveel mogelijk na te bootsen om vertaling naar de praktijk mogelijk te maken.

3. Ontbreken van een gewenningsperiode voorafgaand aan het uiteindelijke experiment. Voorafgaand aan het experiment werden de dieren tussen 20 en 50 weken leeftijd eenmaal daags in de ochtend gevoerd waardoor het metabolisme op die situatie geconditioneerd wordt. In een volgend experiment zal een pre-experimentele periode ingebouwd worden van minimaal 2 weken waarin de betreffende hokken tweemaal daags (controle) voer verstrekt krijgen.

\subsection{Effect voerstrategie op gedrag}

Uit de gedragswaarnemingen komt duidelijk naar voren dat de tweemaal per dag gevoerde dieren (CON2x en SP2x) een ander gedragspatroon hebben dan de eenmaal per dag gevoerde dieren. In figuur 3.3 zijn de verschillende gedragingen naar soort gemiddeld: eten/drinken, rusten (staan en zitten), lopen-foerageren, verzorging (comfort en stofbad) en pikken (object en andere kippen) weergegeven. Hierbij zijn de tweemaal per dag gevoerde dieren (CON2x en SP2x) gemiddeld weergegeven. 

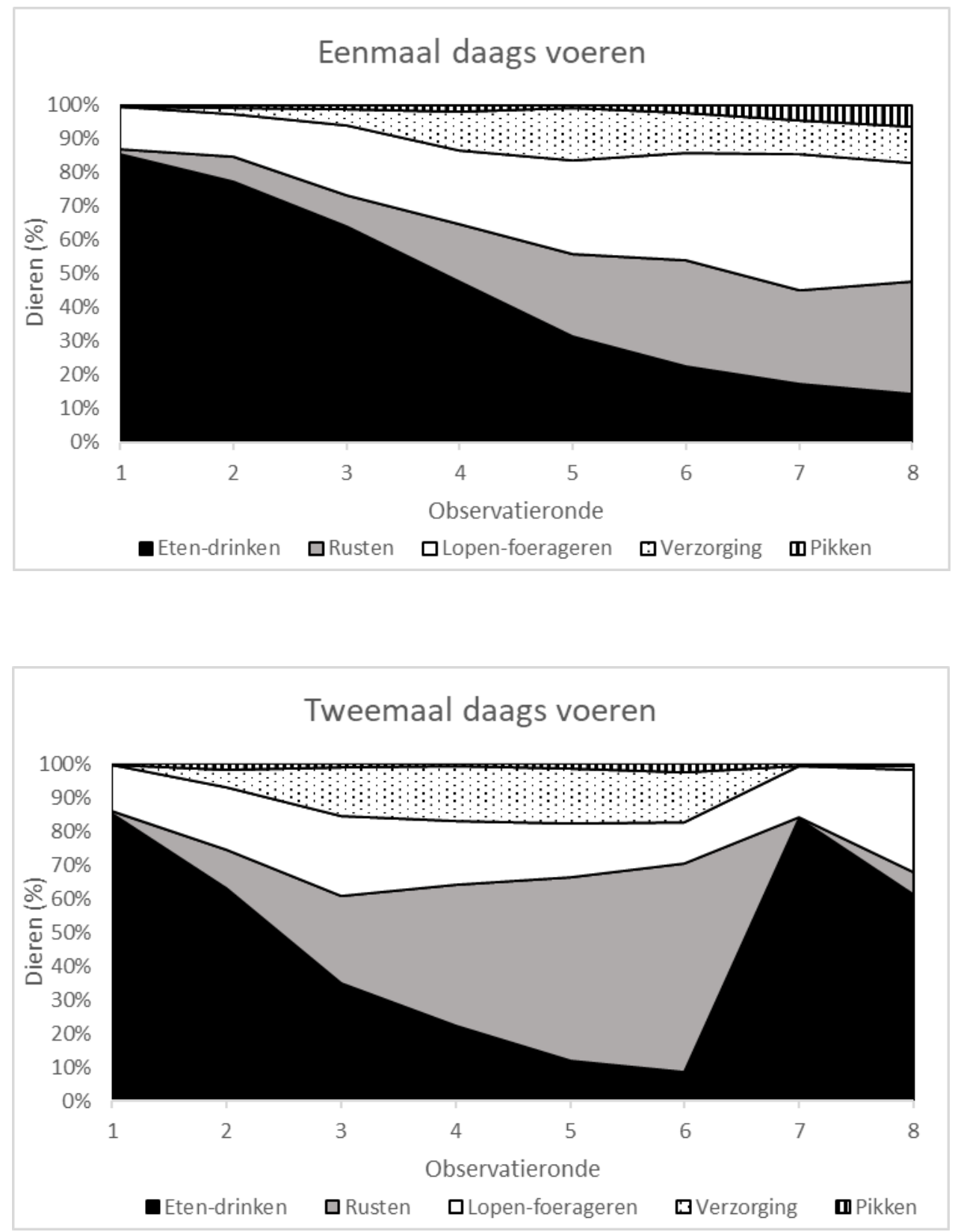

Figuur 3.3 Effect van eenmaal (boven) of tweemaal (onder) daags voeren op de ontwikkeling van de verschillende hoofdgroepen gedragingen gedurende de dag.

Uit de grafieken blijkt dat de dieren die eenmaal per dag gevoerd werden gedurende de dag steeds minder tijd besteden aan eten/drinken opnemen. Dit is logisch omdat de dieren 's ochtends eenmaal gevoerd werden en dit voer langzaam maar zeker opraakte. De dieren die tweemaal per dag gevoerd werden besteden 's morgens relatief minder tijd aan eten/drinken omdat zij 's ochtends $50 \%$ van de dagportie kregen en dit sneller opnamen. In de middag was er na de tweede voerbeurt een flinke toename van het eten/drinken gedrag te zien. Uit de figuren blijkt verder dat de dieren die tweemaal per dag gevoerd werden in de ochtend en rond de middag voor de tweede voerbeurt meer tijd besteden aan rusten (staan en zitten). Die dieren die eenmaal per dag gevoerd werden, vertoonden meer rustgedrag aan het einde van de dag. Dit kan mogelijk nadelig zijn voor het paargedrag en de bevruchting van de broedeieren. Uit onderzoek van Harris et al. (1980) en Bilcik en Estevez (2008) is bekend dat aan het einde van de dag de meeste paringsactiviteit plaats vind. De laatste drie tot vier uur van de dag (lichtperiode) is van oorsprong namelijk biologisch en fysiologisch het ideale moment voor paargedrag. Meer activiteit en vooral mengen van de hennen en hanen in de namiddag leidt tot meer paringsactiviteit en daarmee een goede persistente bevruchting bij het ouder worden van de dieren (van Emous, 2010). 
Er was een verschil tussen rusten, lopen-foerageren en pikken tussen de dieren die een- of tweemaal daags gevoerd werden. De tweemaal per dag gevoerde dieren vertoonden gemiddeld 6,4\% (25,3 vs. $18,9 \% ; P<0,001)$ meer rustgedrag dan de eenmaal per dag gevoerde dieren. De tweemaal daags gevoerde dieren vertoonden gemiddeld 6,8\% (18,5 vs. $25,3 \% ; P<0,001)$ minder lopen-foerageer gedrag. Daarnaast werd de helft ( 1,2 vs. $2,4 \% ; P<0,001)$ minder pikgedrag (naar object en kippen) waargenomen bij de tweemaal t.o.v. de eenmaal per dag gevoerde dieren. In het algemeen lag het totaal pikgedrag (minder dan $2 \%$ ) op een laag niveau, wat overeenkomt met eerder onderzoek van de Jong et al. (2005), Sandilands et al. (2005) en van Emous et al. (2015). In bijvoorbeeld het onderzoek van van Emous et al. (2015) werd gemiddeld minder dan 3\% pikgedrag waargenomen op 46 en 54 weken leeftijd. 


\section{Conclusies en aanbevelingen}

\section{Conclusies}

Uit het onderzoek blijkt dat dieren die split-feeding kregen een hogere productie hadden tussen 51 en 55 weken leeftijd. Verder gaf het toepassen van tweemaal daags voeren (twice a day-feeding en splitfeeding) nauwelijks effecten op productie en broedeikwaliteit. Wel werd bij de verschillende voerstrategieën een duidelijk ander gedragspatroon gedurende de dag waargenomen. De tweemaal daags gevoerde dieren vertoonden t.o.v. eenmaal daags gevoerde dieren meer eet en rust gedrag en minder foerageer en pik gedrag. Verder onderzoek met een aangepaste opzet van het experiment is wenselijk om uit te zoeken wat de voordelen op reproductie, broedeikwaliteit en gedrag zijn van splitfeeding en twice a day-feeding.

Aanbevelingen voor vervolgonderzoek

1. Toepassen van tweemaal daags voeren (twice a day-feeding en split-feeding) gedurende een langere periode (bv. 45 tot en met 65 weken leeftijd).

2. Toegepaste gehaltes van de proefvoeders in het huidige experiment evalueren en aanpassen. Bijvoorbeeld een hoger energieniveau in het ochtendvoer.

3. Verstrekken van extra grit aanpassen aan totale calciumbehoefte in het rantsoen.

4. Een pre-experimentele periode inplannen van minimaal 2 weken waarin de dieren kunnen wennen aan het tweemaal daags voeren.

5. Krijt/kalksteentjes verhouding bij split-feeding aanpassen. Bijvoorbeeld door $80-90 \% \mathrm{krijt}$ in het ochtendvoer en $80-90 \%$ kalksteentjes in het middagvoer. 


\section{Literatuur}

Aviagen-EPI. 2017. Managementgids Ross 308 ouderdieren. Roermond, Nederland.

Backhouse, D., Gous, R.M. 2005. The effect of feeding time on shell quality and oviposition time in broiler breeders. Br. Poult. Sci. 46:255-259.

Backhouse, D., Gous, R.M. 2006. Responses of adult broiler breeders to feeding time. Worlds Poult. Sci. J. 62:269-281.

Bilcik, B., Estevez, I. 2005. Impact of male-male competition and morphological traits on mating strategies and reproductive success in broiler breeders. Appl. Anim. Behav. Sci. 92:307-323.

Bilcik, B., Keeling., L.J. 1999. 'Changes in Feather Condition in Relation to Feather Pecking and Aggressive Behaviour in Laying Hens'. Br. Poult. Sci. 40:444-51.

Bootwalla, S.M., Wilson, H.R., Harms, R.H. 1983. Performance of broiler breeders on different feeding systems. Poult. Sci. 62:2321-2325.

Brake, J., 1985. Relationship of egg weight, specific gravity, and shell weight to time of oviposition and feeding in broiler breeders. Poult. Sci. 64:2037-2040.

Cave, N.A., 1981. Effect of diurnal programs of nutrient intake on the performance of broiler breeder hens. Poult. Sci. 60:1287-1292.

de Avila, V.S., Penz Jr., A.M., De Brum, P.A.R., Rosa, P.S., Guidoni, A.L., De Figueiredo, É.A.P. 2003. Performance of female broiler breeders submitted to different feeding schedules. Br. J. Poult. Sci. 5:197-201.

de Jong, I. C., H. Enting, A. van Voorst, H.J. Blokhuis. 2005. Do low-density diets improve broiler breeder welfare during rearing and laying? Poult. Sci. 84:194-203.

de Los Mozos, J., Sanchez. F. 2014. Split feeding meets layers' specific needs. http://www.thepoultrysite.com/articles/3091/split-feeding-system-for-more-sustainable-eggproduction

Farmer, M., Roland Sr., D.A., Brake, J., Eckman, M.K. 1983a. Calcium metabolism in broiler breeder hens. 1. Calcium status of the digestive tract of broiler breeders throughout a 24 hour period. Poult. Sci. 62:459-464.

Farmer, M., Roland Sr., D.A., Eckman, M.K. 1983b. Calcium metabolism in broiler breeder hens. 2. The influence of the time of feeding on calcium status of the digestive system and egg shell quality in broiler breeders. Poult. Sci. 62:465-471.

Gauthier, R. 2002. La salud intestinal: clave de la productividad (El caso de los Ácidos Orgânicos). In: Precongreso Cientifico Avicola IASA, XXVIIConvencion ANECAWPDC. Anais eletrônicos, Puerto Vallarta, Jal. Méxicohttp://www.engormix.com/MA-avicultura/nutricion/articulos/salud-intestinalclave-productividad-t518/p0.htm [Accessed 8.8.13].

Genstat. 2018. Genstat 19th Reference Manual: Release 1. Clarendon Press, Oxford, UK.

Harms, R.H., 1991. The influence of changing time of feeding on performance of broiler breeder hens. Poult. Sci. 70:1695-1698.

Harris, G.C., jr, Benson, J., Sellers, T.A., Cole, T.A. 1980. The mating activity of broiler breeder cockerels. Arkansas Farm Res. 29:15.

Hebbink, L. 2018. 'Eggshell mottling, does it affect incubation results? | Pas Reform Hatchery Technologies'. 28 oktober 2018. https://www.pasreform.com/en/knowledge/126/eggshellmottling-does-it-affect-incubation-results.

Londero, A., Rosa, A.P., Giacomini, C.B.S., Vivas, C.E.B., Orso, C., de Freitas, H.M., Gressler, L.T., Vargas, A.C. 2015. Effect of different feeding schedules on reproductive parameters and egg quality of broiler breeders. Anim. Feed Sci. Tech. 210:165-171.

Moradi, S., Zaghari, M., Shivazad, M., Osfoori, R., Mardi, M. 2013. The effect of increasing feeding frequency on performance, plasma hormones and metabolites, and hepatic lipid metabolism of broiler breeder hens. Poult. Sci. 92:1227-1237.

Roland Sr., D.A., Farmer, M. 1984. Egg shell quality II: importance of time of calcium intake with emphasis on broiler breeders. Worlds Poult. Sci. J. 40:255-260.

Samara, M.H., Robbins, K.R., Smith, M.O. 1996. Interaction of feeding time and temperature and their relationship to performance of the broiler breeder hen. Poult. Sci. 75:34-41.

Sandilands, V., Tolkamp, B.J., Kyriazakis, I. 2005. Behaviour of food restricted broilers during rearing and lay - effects of an alternative feeding method. Phys. and Behav. 85:115-123. 
Soltanmoradi, M.G., Seidavi, A., Dadashbeiki, M., Delgado, F., Gamboa, S. 2013. Effect of time, amount and frequency of feeding on total egg production, fertility and hatchability in broiler breeders. Arch. Tierzucht: Arch. Anim. Breed. 56:102.

Spradley, J.M., Freeman, M.E., Wilson, J.L., Davis, A.J. 2008. The influence of a twice-a-day feeding regimen after photostimulation on the reproductive performance of broiler breeder hens. Poult. Sci. 87:561-568.

Taherkhani, R., Zaghari, M., Shivazad, M., Zare Shahneh, A. 2010. A twice-a-day feeding regimen optimizes performance in broiler breeder hens. Poult. Sci. 89:1692-1702.

van Emous, R.A. 2010. Quality Time $®$ : an innovative housing concept for broiler breeders. In: Proceedings of the 2nd International symposium. Highlights in nutrition and welfare in poultry production. Wageningen, The Netherlands 2010. pp. 37-44.

van Emous, R.A., Kwakkel, R.P., van Krimpen, M.M., Hendriks, W.H. 2015. Effects of different dietary protein levels during rearing and different dietary energy levels during lay on behaviour and feather cover in broiler breeder females. Appl. Anim. Behav. Sci. 168:45-55.

van Krimpen, M.M., van Binnendijk, G.P., van Emous, R.A. 2018. 'Effect van split-feeding bij biologisch gehouden leghennen op de fosforexcretie en schaalkwaliteit'. Wageningen Livestock Research.

Warin, S. 2009. 'Embryonic Development, Day by Day'. 1 juli 2009. https://thepoultrysite.com/articles/embryonic-development-day-by-day.

Wilson, H.R., Keeling, L.J., 1991. Effect of time of feeding on oviposition time and production parameters in broiler breeders. Poult. Sci. 70:254-259. 


\section{Bijlage 1 Schematisch overzicht hok}

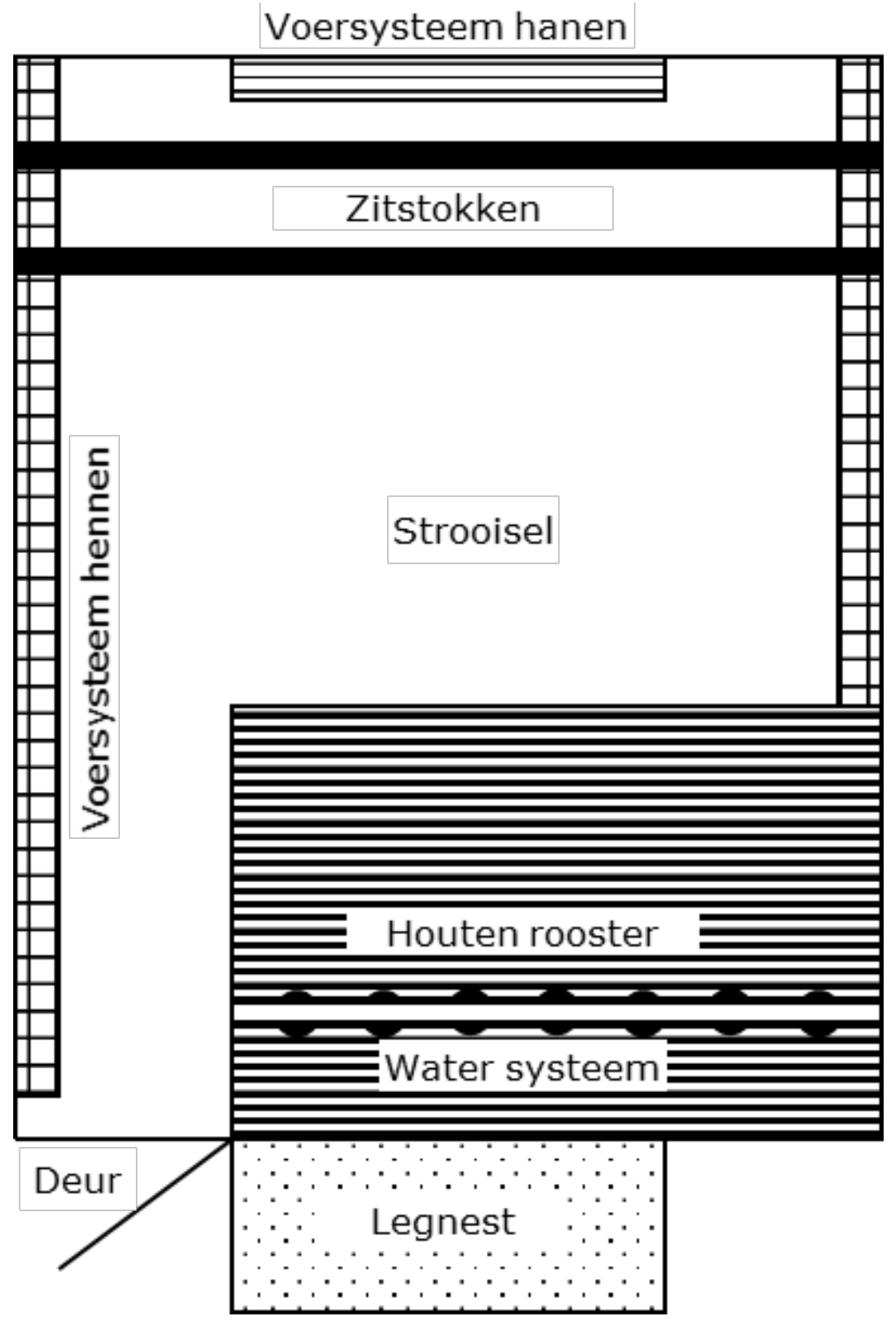




\section{Bijlage 2 Samenstelling voeders}

Controlevoer

Ochtendvoer

Middagvoer

\begin{tabular}{|c|c|c|c|}
\hline \multicolumn{4}{|l|}{ Ingrediënt $(\mathbf{g} / \mathbf{k g})$} \\
\hline Mais & 358,2 & 358,2 & 358,2 \\
\hline Tarwe & 314,3 & 310,7 & 302,1 \\
\hline Raapzaadschilfers & 55,1 & 29,6 & 29,6 \\
\hline Raapzaadschroot & 24,5 & 50,0 & 50,0 \\
\hline Sojaschroot & 10,0 & 19,9 & 10,0 \\
\hline Zonnebloemschroot & 110,0 & 119,7 & 99,2 \\
\hline Palmolie & 10,0 & 10,0 & 10,0 \\
\hline Sojaolie & 10,2 & 9,3 & 8,0 \\
\hline Zalmolie & 4,0 & 4,0 & 4,0 \\
\hline Salcurb Dry K2 & 7,5 & 7,5 & 7,5 \\
\hline Kalksteentjes fijn & 71,5 & 57,7 & 99,5 \\
\hline Krijt & 10,0 & 10,0 & 10,0 \\
\hline Mono-Cal fosfaat & 1,7 & 1,4 & 0,0 \\
\hline Natriumbicarbonaat & 2,7 & 2,5 & 2,4 \\
\hline Zout & 1,4 & 1,6 & 1,5 \\
\hline Foktoom premix & 4,0 & 4,0 & 4,0 \\
\hline DL-Methionine & 0,5 & 0,5 & 0,0 \\
\hline L-Lysine HCL & 1,1 & 0,5 & 0,8 \\
\hline L-Threonine & 0,8 & 0,5 & 0,6 \\
\hline M2342 Glu-Xyl & 2,5 & 2,5 & 2,5 \\
\hline \multicolumn{4}{|l|}{ Berekend $(\mathbf{g} / \mathbf{k g})$} \\
\hline OEleg (kcal/kg) & 2760 & 2766 & 2669 \\
\hline Drogestof & 897,7 & 896,2 & 900,2 \\
\hline Ruw as & 110,8 & 98,0 & 136,1 \\
\hline Ruw eiwit & 133,5 & 140,0 & 127,5 \\
\hline Ruw vet & 49,1 & 47,0 & 45,0 \\
\hline $\mathrm{C} 18: 2$ & 16,5 & 15,9 & 14,9 \\
\hline Ruwe celstof & 45,0 & 47,0 & 43,1 \\
\hline Zetmeel & 430,6 & 430,2 & 423,8 \\
\hline OEpl (kcal/kg) & 2800 & 2800 & 2705 \\
\hline Calcium & 34,0 & 28,7 & 44,5 \\
\hline Fosfor, totaal & 4,16 & 4,24 & 3,61 \\
\hline Fosfor, opneembaar & 2,80 & 3,03 & 2,18 \\
\hline Magnesium & 2,02 & 2,03 & 2,08 \\
\hline Natrium & 1,40 & 1,40 & 1,40 \\
\hline Kalium & 5,49 & 5,85 & 5,32 \\
\hline Chloride & 1,60 & 1,60 & 1,60 \\
\hline EB (meq) & 156 & 166 & 152 \\
\hline vLysine & 4,90 & 4,83 & 4,47 \\
\hline vMethionine & 3,00 & 3,14 & 2,40 \\
\hline $\mathrm{VM}+\mathrm{C}$ & 5,18 & 5,43 & 4,48 \\
\hline vThreonine & 4,66 & 4,58 & 4,25 \\
\hline vTryptofaan & 1,27 & 1,37 & 1,21 \\
\hline \multicolumn{4}{|c|}{ Geanalyseeerd $(\mathrm{g} / \mathrm{kg})$} \\
\hline Droge stof & 890,0 & 887,0 & 894,0 \\
\hline Ruw as & 108,0 & 87,0 & 142,0 \\
\hline Ruw eiwit & 138,0 & 148,0 & 129,0 \\
\hline Ruw vet & 47,0 & 48,0 & 44,0 \\
\hline Ruwe celstof & 43,0 & 51,0 & 39,0 \\
\hline Calcium totaal & 37,4 & 27,2 & 53,2 \\
\hline Fosfor totaal & 4,43 & 4,92 & 3,96 \\
\hline
\end{tabular}




\section{Bijlage 3 Ethogram algemeen gedrag}

\begin{tabular}{|l|l|}
\hline Gedrag & Beschrijving \\
\hline Eten & Pikken naar voer in het voersysteem \\
\hline Drinken & Pikken naar water in het watersysteem \\
\hline Staan & Staan zonder uitvoeren van ander gedrag \\
\hline Zitten & Zitten zonder uitvoeren van ander gedrag \\
\hline Lopen & Lopen zonder uitvoeren van ander gedrag \\
\hline Foerageren & Foerageren zonder uitvoeren van ander gedrag \\
\hline Verzorging & $\begin{array}{l}\text { Al het verzorgingsgedrag (zonder stofbaden), zoals verenpoetsen, } \\
\text { zelf pikken, knabbelen, aaien, vleugelslaan en strekken }\end{array}$ \\
\hline Stofbaden & Stofbaden zonder uitvoeren van ander gedrag \\
\hline Object pikken & Object pikken zonder uitvoeren van ander gedrag \\
\hline Kip pikken & Kip pikken zonder uitvoeren van ander gedrag \\
\hline
\end{tabular}




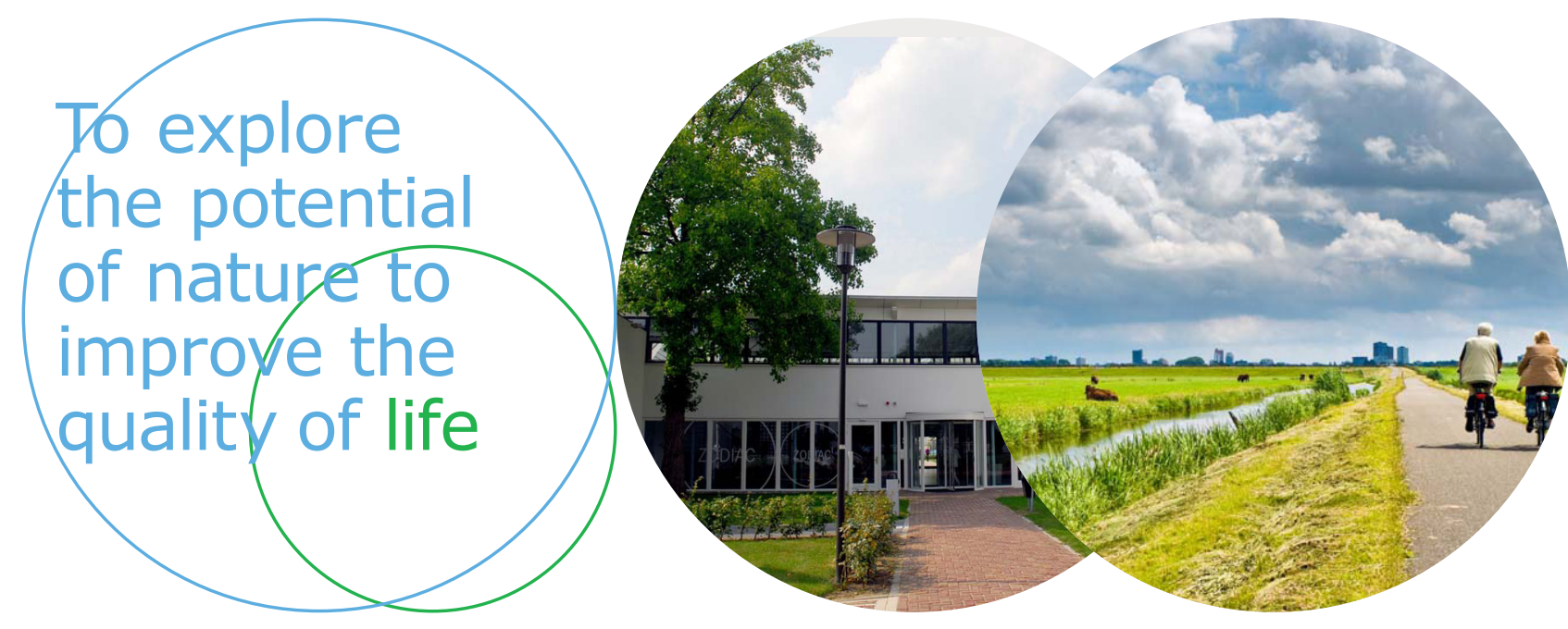

Wageningen Livestock Research Postbus 338

$6700 \mathrm{AH}$ Wageningen

T 0317483953

E info.livestockresearch@wur.nl www.wur.nl/livestock-research
Wageningen Livestock Research ontwikkelt kennis voor een zorgvuldige en renderende veehouderij, vertaalt deze naar praktijkgerichte oplossingen en innovaties, en zorgt voor doorstroming van deze kennis. Onze wetenschappelijke kennis op het gebied van veehouderijsystemen en van voeding, genetica, welzijn en milieu-impact van landbouwhuisdieren integreren we, samen met onze klanten, tot veehouderijconcepten voor de $21 \mathrm{e}$ eeuw.

De missie van Wageningen University \& Research is 'To explore the potential of nature to improve the quality of life'. Binnen Wageningen University \& Research bundelen 9 gespecialiseerde onderzoeksinstituten van Stichting Wageningen Research en Wageningen University hun krachten om bij te dragen aan de oplossing van belangrijke vragen in het domein van gezonde voeding en leefomgeving. Met ongeveer 30 vestigingen, 6.500 medewerkers en 10.000 studenten behoort Wageningen University \& Research wereldwijd tot de aansprekende kennisinstellingen binnen haar domein. De integrale benadering van de vraagstukken en de samenwerking tussen verschillende disciplines vormen het hart van de unieke Wageningen aanpak. 